\title{
34. RADIOMETRIC AGES OF BASALTS FROM DSDP LEG 43: SITES 382 AND 385 (NEW ENGLAND SEAMOUNTS), 384 (J-ANOMALY), 386 AND 387 (CENTRAL AND WESTERN BERMUDA RISE)
}

Robert L. Houghton, Department of Earth and Planetary Sciences, Massachusetts Institute of Technology, Cambridge, Massachussets, and Department of Geology and Geophysics, Woods Hole Oceanographic Institution, Woods Hole, Massachusetts

J. Elliott Thomas, Jr., Stone \& Webster Engineering Corporation, Boston, Massachusetts and

Richard J. Diecchio and Angelo Tagliacozzo, Stone \& Webster Engineering Corporation, New York, New York

\begin{abstract}
${ }^{40} \mathrm{Ar} /{ }^{39} \mathrm{Ar}$ and conventional $\mathrm{K}$-Ar dating techniques were employed to determine the age of basalts recovered on Leg 43 of the Deep Sea Drilling Project (DSDP), and the results were compared with paleontologic ages of sediments immediately overlying basement. As all of the samples are moderately altered, their radiometric ages must be regarded as minimums.

Ages from basaltic clasts recovered from the volcaniclastic breccia at Site 382 on Nashville Seamount range from $79 \pm 4$ m.y. to $88.3 \pm 5.7$ m.y. The latter is the crystallization age of hornblende in the basalt. This date compares favorably with a $91-95$ m.y. age predicted by extrapolation of sediment accumulation rates. Breccia clasts at Site 385 on Vogel Seamount range from $38.3 \pm 15$ m.y. to $91.2 \pm 3$ m.y., the younger ages being the product of extreme weathering of the basalt, and the older the crystallization age of phyric hornblende. Extrapolation of sedimentation rates suggests a 75.5 to 77.5 m.y. age for the top of the lower breccia unit. A basaltic sill drilled at Site 385 , which yields a $21.0 \pm 3$ m.y. age, is geochemically similar to another Miocene sill recovered at DSDP Site 10. On the basis of two holes along the New England seamount chain, volcanism appears to have been simultaneous, but a migratory hot spot character cannot be ruled out.

Basalt recovered at Site 384 on the $J$-Anomaly Ridge yields ${ }^{40} \mathrm{Ar} /$ ${ }^{39} \mathrm{Ar}$ and $\mathrm{K}-\mathrm{Ar}$ ages of $88 \pm 5$ m.y. and $106 \pm 4$ m.y., respectively. Nannofossil assemblages suggest the basement contact to be $\sim 104$ 107 m.y. old.

The radiometric age of altered basalt at Site 386 on the central Bermuda Rise ranges from $110 \pm 20$ m.y. to $153 \pm 18$ m.y.; our best estimate of absolute basement age is $125 \pm 25 \mathrm{~m}$.y. Unbaked sapropelic clay overlying the basalt has been paleontologically dated as 106 to 112 m.y. old. Site 387 on the western Bermuda Rise also yielded hydrothermally altered basalt, making radiometric dating difficult. A gas retention age of $126 \pm 20$ m.y. is suggested. Baked sediment within the basalt accurately dates this sill as 128133 m.y. old. True basement is probably contemporaneous. The sediment ages support the Larson-Pitman fast-spreading episode in the mid-Cretaceous for the western North Atlantic basin.
\end{abstract}

\section{INTRODUCTION}

Basalt was recovered at five of the six sites drilled on Leg 43. The objective of this study was to determine the ages of crystallization of these basalts by radiometric dating techniques.

Site 382 was drilled into the volcaniclastic apron of Nashville Seamount $18 \mathrm{~km}$ east-southeast of the eastern-most peak of the chain (latitude $35^{\circ} 25.04^{\prime} \mathrm{N}$; longitude $56^{\circ} 32.25^{\prime} \mathrm{W}$; water depth, $5526 \mathrm{~m}$ ). Pleisto- cene to Upper Cretaceous (Coniacian-Santonian or older) sediments, 520.5 meters thick, were penetrated. Although basement was not reached, two units of volcaniclastic sandstone and breccia at the base of the hole, totaling 67 meters in thickness, yielded abundant basaltic lapilli (see Site 382 Report, Lithology, this volume). The clasts range widely in degree of alteration, and thus is exposure thing to sea water, suggesting that basalts from several episodes of seamount volcanism are represented. As only the freshest material was 
datable, we believe that the results represent the latest volcanism on Nashville. Clast size and degree of alteration favored dating of the lower breccia (Sub-unit $3 \mathrm{~F})$ at this site. In view of the principal objective of this site of testing the hot-spot hypothesis for the origin of the New England seamount chain (see Coney, 1971; Vogt et al., 1971; Morgan, 1973; Vogt, 1973), it is important to point out that resultant dates probably represent the age of cessation of volcanism on Nashville.

All basaltic clasts studied from the breccia unit are strongly alkalic and are probably derived from flows capping the peaks of the seamount (Houghton, this volume). Three of the petrographically freshest clasts were dated. The clasts are moderately altered, medium dark gray, hypocrystalline, porphyritic basalts with doleritic to intersertal groundmass textures. Phenocryst phases are plagioclase, hornblende, and pyroxene. The plagioclase is moderately altered to montmorillonite, but in places is fairly fresh between altered cores and rims. Montmorillonite and zeolite have completely replaced former glass, and combine with calcite and minor magnetite to fill vesicles. Phyric hornblende and clinopyroxene are only slightly altered; the former is clear, not patchy, and free from cracks or alteration rims, while the latter is in places partly altered to kaersutite. Zoning and the extreme size of the hornblende crystals (up to several centimeters) precludes a secondary origin for the amphibole. Groundmass pyroxene is partially to mostly replaced by montmorillonite. The petrography and petrology of the Leg 43 basalts are more fully described by Houghton (this volume).

Site 385 was drilled through 392.9 meters of Pleistocene to Upper Cretaceous sediments that constitute the sedimentary apron on the northern flank of Vogel Seamount (latitude $37^{\circ} 22.17^{\prime} \mathrm{N}$; longitude $60^{\circ} 09.45^{\prime} \mathrm{W}$; water depth, $4936 \mathrm{~m}$ ). As at Site 382 , the hole was terminated after penetrating 55 meters of volcaniclastic sandstone and breccia. The paleontologic age at the base of the hole is unknown because no fossils were recovered from within the volcaniclastic unit. Extrapolation of sediment accumulation rates suggests dates ranging from Turonian to Campanian. Basaltic clasts recovered from this breccia are petrographically similar to those found on Nashville, but plagioclase alteration to montmorillonite is more pervasive. Three moderately altered clasts of alkalic basalt were dated.

In addition to the basaltic breccias, two aphanitic, grayish brown basalt fragments with lineations of unfilled vesicles were recovered at 283 meters, within Upper Cretaceous clays. They probably represent a sill. Petrographically, the basalt is a holocrystalline, microcrystalline aphanite with a felted pilotaxitic texture. Although plagioclase microlites are only slightly altered to montmorillonite, this clay mineral combines with chlorite to fill vesicles. One quarter-section of the freshest of these fragments was dated.

A 330.3-meter section was drilled at Site 384 on the $J$-Anomaly Ridge where it emerges above the lower continental rise south of the Grand Banks (latitude $40^{\circ} 21.65^{\prime} \mathrm{N}$; longitude $51^{\circ} 29.80^{\prime} \mathrm{W}$; water depth, 2909 $\mathrm{m})$. The hole penetrated 324.8 meters of middle Eocene (or younger) to Aptian (or older) sediments and 5.5 meters of basement basalt. A minimum of two flow units are present. The basalts are abyssal tholeiites lacking any chemical anomalies capable of giving rise to the $J$ anomaly.

Petrographically, both units consist of moderately to extensively altered hypocrystalline, fine-grained, amygdaloidal phyric basalt with a pilotaxitic texture. Minor fluxion of plagioclase microlites aroung phenocrysts and amygdules has occurred. As the upper unit is intensely weathered, two $1-\mathrm{cm}$ long pieces of $2.2-\mathrm{cm}$ diameter core (drilled at right angles to the DSDP core) were taken from the lower flow unit for dating. The rocks are moderately altered, but plagioclase and pyroxene phenocrysts are only slightly altered to montmorillonite. Vesicles are completely filled with montmorillonite and chlorite, and groundmass glass is mostly devitrified and altered to montmorillonite and zeolite.

Site 386 was drilled on the central Bermuda Rise $140 \mathrm{~km}$ south-southeast of Bermuda (latitude $31^{\circ} 11.21^{\prime} \mathrm{N}$; longitude $64^{\circ} 14.94^{\prime} \mathrm{W}$; water depth, 4732 $\mathrm{m})$. Objectives included obtaining a basement age in this older portion of the Cretaceous "quiet zone." The hole penetrated 964.2 meters of lower Pleistocene to Lower Cretaceous (upper Aptian-lower Albian) sediments and about 9.6 meters of basement basalt. Identification of flow contacts is difficult because of extensive veining throughout.

A total of 2.1 meters of abyssal tholeiite was recovered from Site 386 . Texturally, this basement rock is a hypocrystalline, fine-grained, amygdaloidal, phyric basalt with an intersertal to "feather duster" groundmass. Plagioclase phenocrysts are relatively fresh, and only slightly turbid from clay mineral alteration. Pyroxene phenocrysts are extensively altered to montmorillonite and chlorite. Matrix glass and pyroxene are similarly altered. The degree of weathering increases upward. Between 966.3 and 967.0 meters, the basalt is intersected by a segregation of calcite bounded by serpentinized slickensides which we interpret as a hydrothermal vein. Immediately beneath the vein, the basalt is stained with native sulfur. The freshest basalt was obtained from the lowest part of the recovered core, at a nominal depth of 973.8 meters. Two transverse cores were taken from this least-altered material for dating.

Site 387 was drilled on the western Bermuda Rise at latitude $32^{\circ} 19.2^{\prime} \mathrm{N}$, longitude $67^{\circ} 40^{\prime} \mathrm{W}$, and in a water depth of 5117 meters. This hole penetrated 791.6 meters of Pleistocene to Lower Cretaceous (upper Berriasian-lower Valanginian) sediment and 2.9 meters of underlying basalt. An objective of the basement recovery program at this site was the dating of anomalies $M-15 / M-16$ of the Keathley Sequence ( $M$-series).

The basalt is a grayish blac, holocrystalline, finegrained, amygdaloidal, phyric basalt, characterized by a variable groundmass texture and local enclosures of calcareous claystone. Phyric plagioclase and pyroxene 
have been corroded by early resorption but are only slightly altered to montmorillonite. Scarce vesicles are filled with montmorillonite, calcite, and minor chlorite. Calcite veins occur throughout. A single transverse core section was obtained for dating in the upper, more weathered portion of the unit because it is more free of calcite veins and sediment. On the basis of total recovery, a baked sediment contact, sediment enclosures, and gradation inward to a coarser matrix, the basalt is interpreted to be a sill. Comparison with a similar section of sills and flows drilled on Leg 37 suggests that the sill is similar in age to the original oceanic crust at Site 387.

\section{EXPERIMENTAL TECHNIQUES}

Six samples were chosen for ${ }^{40} \mathrm{Ar} /{ }^{39} \mathrm{Ar}$ incremental heating analysis and another seven for conventional $\mathrm{K}-\mathrm{Ar}$ dating. The former were determined by John Sutter and Bob Duncan according to the technique of Sigurgeirsson (1962) and Merrihue (1965), as modified by Dalrymple and Lanphere (1971). All ${ }^{40} \mathrm{Ar} /{ }^{39} \mathrm{Ar}$ samples $(-30,+60$ mesh $)$ were encapsuled in pure quartz vials and irradiated in the core facility of the U.S. Geological Survey TRIGA Reactor in Denver, Colorado, using an 800-m.y.-old biotite standard. Following irradiation, each sample was heated by radiofrequency induction in a static vacuum to liberate gases. Heating was incremental, at successively higher temperatures, to the point of fusion. The argon from each temperature increment was purified, and its isotopic composition measured on a mass spectrometer. Each temperature increment was treated as a separate unknown, and the argon isotopic data were used to calculate the age of each temperature increment in the samples after correction for geometry in the reactor during irradiation. As the $\mathrm{K} / \mathrm{Ca}$ of these samples is low, corrections for $\mathrm{K}$-derived ${ }^{40} \mathrm{Ar}$ and $\mathrm{Ca}$-derived ${ }^{36} \mathrm{Ar}$ and ${ }^{39} \mathrm{Ar}$ were also made along with those for atmospheric argon contamination.

$\mathrm{K}$-Ar ages were determined by Bob Duncan and by Krueger Enterprises, Inc., using conventional techniques (Lanphere and Dalrymple, 1967). Argon measurements were made using standard isotope dilution techniques (Dalrymple and Lanphere, 1969). Flame photometry using lithium metaborate fusion (Ingamells, 1970) was used to analyze for potassium.

Pure concentrates of mineral separates were prepared at Massachusetts Institute of Technology and provided to the analyzing laboratory. Hornblende phenocrysts were separated using sonic sieving, heavy liquid, and magnetic separation techniques. Before final density separation, the hornblende separates were treated for 3 minutes in a 5 per cent solution of cold HF, after which they were cleaned in distilled water with an ultrasonic cleaner. The procedure was repeated when necessary, and final separation was performed by hand picking.

All of the samples show slight to moderate alteration. As none meet the usual criteria of reliability for whole-rock K-Ar dating (Dalrymple and Lanphere, 1969; Mankinen and Dalrymple, 1972), the calculated whole-rock $\mathrm{K}$-Ar ages must be regarded as minimum ages. ${ }^{40} \mathrm{Ar} /{ }^{39} \mathrm{Ar}$ dates must be evaluated individually on the basis of their incremental-temperature versus apparent-age plot. Calculated ages in Tables 1 through 6 are credited to their respective laboratories.

\section{RESULTS AND DISCUSSION}

\section{Site 382}

Clast size and degree of alteration favored dating of the lower breccia unit of this site. The results of ${ }^{40} \mathrm{Ar} /$ ${ }^{39} \mathrm{Ar}$ incremental heating analysis on a relatively fresh basaltic clast from the volcaniclastic breccia (382-25CC, $35-40 \mathrm{~cm}$ ) are presented in Table 1. The lowtemperature increments yield anomalously old ages while the ages resulting from high temperature increments are nearly constant, with an argon retention age of $79 \pm 4$ m.y. (Figure 1). If a thermal event occurred with temperatures sufficiently low to cause loss of less than about 20 per cent of the radiogenic ${ }^{40} \mathrm{Ar}$, low apparent ages would be observed for low-temperature increments. Thus, thermal activity cannot explain the older ages seen for this basalt. Little work has been done to investigate the effect of sea water on ${ }^{40} \mathrm{Ar} /{ }^{39} \mathrm{Ar}$ dates, so weathering of the basalts could explain the anomalous age observed here. However, the high apparent ages from gas released at low temperature may also indicate excess argon. ${ }^{40} \mathrm{Ar} /{ }^{39} \mathrm{Ar}$ analysis of a chemically similar but more weathered basalt from Vogel Seamount $(385-20-2,34-42 \mathrm{~cm})$ displays like characteristics (Table 2); its apparent ages continuously decrease with incremental temperature (Figure 2).

Because each date was obtained from a separate clast, evaluation of and correlation between the resultant values are uncertain; however, the argon retention age of $79 \pm 4$ m.y. and the total gas age of $82 \pm 4$ m.y. of $382-25-\mathrm{CC}, 35-40 \mathrm{~cm}$ are consistent with a conventional K-Ar minimum age of $85 \pm 3$ m.y. for 382-23-3, 113-118 (Table 6). The $88.3 \pm 5.7$ m.y. date obtained by conventional $\mathrm{K}$-Ar techniques on the hornblende from the 382-25-2. 91-95 cm, basalt (Table 6) is interpreted as the crystallization age and probably represents the cessation of volcanism on Nashville.

Absence of the nannofossil Tetralithus gothicus in the Globotruncana elevata Zone recovered between 364 and about 412 meters restricts the upper breccia (Sub-unit 3B) to the lower Campanian. Radiometric dating of this volcaniclastic bed was prevented by clast size and the degree of alteration. The sediment immediately overlying the lower breccia (Sub-unit 3F) between 412 and 472 meters is Coniacian/Santonian on the basis of the absence of Broinsonia parca and presence of Lithastrinus grilli. Using the Cretaceous time scale of van Hinte (1976) for the age of the Coniacian/Santonian boundary ( $82 \mathrm{~m} . \mathrm{y}$.), which occurs at about 412 meters, the extrapolated age at the base of Site 382 is 91 m.y. (Figure 3). Obradovich and Cobban (1975) have constructed a time scale based on $\mathrm{K}$-Ar ages of minerals from bentonites intercalated with marine sediments rich in ammonites that may be 
TABLE 1

Analytical Data for ${ }^{40} \mathrm{Ar} /{ }^{39} \mathrm{Ar}$ Incremental Heating Experiment ${ }^{\mathrm{a}}$ Whole Rock $382-25, \mathrm{CC}, 35-40 \mathrm{~cm}$

\begin{tabular}{|c|c|c|c|c|c|c|c|c|}
\hline $\begin{array}{l}\text { Temp. } \\
\text { (C) }\end{array}$ & $\begin{array}{l}{ }^{40} \mathrm{Ar} /{ }^{39} \mathrm{Ar} \\
\text { (Measured) }\end{array}$ & $\begin{array}{l}{ }^{37} \mathrm{Ar} /{ }^{39} \mathrm{Ar} \\
\text { (Corrected for } \\
\text { 37 Ar Decay) }\end{array}$ & $\begin{array}{l}{ }^{36} \mathrm{Ar} /{ }^{39} \mathrm{Ar} \\
\text { (Measured) }\end{array}$ & $F^{\mathrm{b}}$ & $\begin{array}{c}{ }^{39} \mathrm{Ar} \\
\text { (\% of Total) }\end{array}$ & $\begin{array}{c}{ }^{40} \mathrm{Ar}_{\mathrm{r}}{ }^{\mathrm{C}} \\
(\%)\end{array}$ & $\begin{array}{c}{ }^{36} \mathrm{Ar} C \mathrm{Ca} \\
(\%)\end{array}$ & $\begin{array}{c}\text { Aged } \\
\left(\times 10^{6} \mathrm{yr}\right)\end{array}$ \\
\hline 525 & 26.87 & 1.2296 & 0.04674 & 12.89 & 22.63 & 47.97 & 0.72 & $102 \pm 5$ \\
\hline 650 & 18.57 & 1.5874 & 0.01403 & 14.48 & 20.27 & 70.31 & 3.08 & $114 \pm 4$ \\
\hline $750+$ & 15.13 & 1.4790 & 0.01793 & 9.85 & 11.80 & 65.10 & 2.24 & $79 \pm 3$ \\
\hline 850 & 17.75 & 1.4995 & 0.02664 & 9.85 & 5.79 & 55.47 & 1.53 & $79 \pm 4$ \\
\hline 950 & 18.18 & 1.6090 & 0.02774 & 9.96 & 6.70 & 54.74 & 1.58 & $79 \pm 4$ \\
\hline Fusion & 15.15 & 15.0845 & 0.02365 & 9.34 & 32.81 & 61.12 & 17.35 & $75 \pm 3$ \\
\hline \multicolumn{9}{|l|}{ Total } \\
\hline Gas & 17.88 & 5.9189 & 0.02670 & 10.35 & 100.10 & 57.73 & 6.03 & $82 \pm 4$ \\
\hline
\end{tabular}

aEach temperature was held for one hour. $J=0.004315 \pm 0.000035$. Analysis by John F. Sutter.

$\mathrm{b}_{F}=\left(A_{u}-C_{1} B_{u}+C_{1} C_{2} D_{u}-C_{3}\right) /\left(1-C_{4} D_{u}\right)$, where $A_{u}$ is the measured ${ }^{40} \mathrm{Ar} /{ }^{39} \mathrm{Ar}$ in the sample; $B_{u}$ is the measured ${ }^{36} \mathrm{Ar} / 39 \mathrm{Ar}$ in the sample; $D_{u}$ is the $37 \mathrm{Ar} / 39 \mathrm{Ar}$ ratio in the sample after correcting for the decay of ${ }^{37} \mathrm{Ar}\left(t_{1 / 2}=35.1\right.$ days); $C_{1}=295.5$, which is the ${ }^{40} \mathrm{Ar} / 36 \mathrm{Ar}$ ratio in the atmosphere; and the correction factors for interfering $\mathrm{Ar}$ isotopes are: $C_{2}=\left({ }^{36} \mathrm{Ar} /{ }^{37} \mathrm{Ar}\right)_{\mathrm{Ca}}=2.72 \times 10^{-4}, C_{3}=\left({ }^{40} \mathrm{Ar} / 39 \mathrm{Ar}\right)_{\mathrm{K}}=5.9 \times$ $10^{-3}$, and $C_{4}=\left({ }^{39} \mathrm{Ar} / 37 \mathrm{Ar}\right)_{\mathrm{Ca}}=6.33 \times 10^{-4}$. These values of $C_{2}, C_{3}$, and $C_{4}$ used to correct the data are those of Dalrymple and Lanphere (1971) for Ca and K salts irradiated at the U. S. Geological Survey TRIGA Reactor in Denver.

c $40 \mathrm{Ar}_{\mathrm{r}}=$ radiogenic ${ }^{40} \mathrm{Ar} ;{ }^{36} \mathrm{Ar}_{\mathrm{Ca}}=$ calcium-derived $36 \mathrm{Ar}$, calculated using data from Dalrymple and Lanphere (1971).

$\mathrm{d}_{\text {Ages were calculated using } t=1 / \lambda} 1 n\left[1+J\left({ }^{40} \mathrm{Ar} /{ }^{39} \mathrm{Ar}_{\mathrm{K}}\right)\right]$, where $1 / \lambda=1.885 \times 10^{9} \mathrm{yr}$ and $J$ is a measure of the integrated fast neutron flux as found from the monitor mineral data. Analytical precision is a $2 \sigma$ error based on extrapolation of data points.

TABLE 2

Analytical Data for ${ }^{40} \mathrm{Ar} /{ }^{39} \mathrm{Ar}$ Incremental Heating Experiment ${ }^{\mathrm{a}}$ Whole Rock $385-20-2,34-42 \mathrm{~cm}$

\begin{tabular}{|c|c|c|c|c|c|c|c|c|}
\hline $\begin{array}{l}\text { Temp. } \\
\text { (C) }\end{array}$ & $\begin{array}{l}{ }^{40} \mathrm{Ar} /{ }^{39} \mathrm{Ar} \\
\text { (Measured) }\end{array}$ & $\begin{array}{l}{ }^{37} \mathrm{Ar} /{ }^{39} \mathrm{Ar} \\
\text { (Corrected for } \\
37 \mathrm{Ar} \text { Decay) }\end{array}$ & $\begin{array}{l}{ }^{36} \mathrm{Ar} /{ }^{39} \mathrm{Ar} \\
\text { (Measured) }\end{array}$ & $F^{\mathrm{b}}$ & $\begin{array}{c}{ }^{39} \mathrm{Ar} \\
\text { (\% of Total) }\end{array}$ & $\begin{array}{l}{ }^{40} \mathrm{Ar}_{\mathrm{r}}{ }^{\mathrm{C}} \\
(\%)\end{array}$ & $\begin{array}{c}{ }^{36} \mathrm{Ar}_{\mathrm{Ca}} \mathrm{Ca} \\
(\%)\end{array}$ & $\begin{array}{c}\text { Aged } \\
\left(\times 10^{6} \mathrm{yr}\right)\end{array}$ \\
\hline 450 & 20.136 & 0.1770 & 0.02555 & 12.46 & 12.75 & 61.84 & 0.19 & $99 \pm 4$ \\
\hline 600 & 9.962 & 0.2654 & 0.00770 & 7.66 & 12.33 & 76.94 & 0.94 & $61 \pm 3$ \\
\hline 700 & 8.184 & 0.2966 & 0.00462 & 6.81 & 10.53 & 83.29 & 1.75 & $55 \pm 2$ \\
\hline 800 & 7.568 & 0.2709 & 0.00396 & 6.39 & 13.09 & 84.54 & 1.86 & $51 \pm 2$ \\
\hline 900 & 6.962 & 0.2224 & 0.00421 & 5.71 & 13.78 & 82.05 & 1.44 & $46 \pm 2$ \\
\hline Fusion & 6.227 & 0.2515 & 0.00460 & 4.86 & 37.50 & 78.06 & 1.48 & $39 \pm 3$ \\
\hline Total & & & & & & & & \\
\hline Gas & 8.943 & 0.2468 & 0.00752 & 6.69 & 100.00 & 74.90 & 0.89 & $54 \pm 3$ \\
\hline
\end{tabular}

aEach temperature was held for one hour. $J=0.004315 \pm 0.000035$. Analysis by John F. Sutter.

$\mathrm{b}_{F}=\left(A_{u}-C_{1} B_{u}+C_{1} C_{2} D_{u}-C_{3}\right) /\left(1-C_{4} D_{u}\right)$, where $A_{u}$ is the measured ${ }^{40} \mathrm{Ar} / 39^{3} \mathrm{Ar}$ in the sample; $B_{u}$ is the measured $36 \mathrm{Ar} / 39 \mathrm{Ar}$ in the sample; $D_{u}$ is the ${ }^{37} \mathrm{Ar} / 39 \mathrm{Ar}$ ratio in the sample after correcting for the decay of $37 \mathrm{Ar}\left(t_{1} / 2=35.1\right.$ days); $C_{1}=295.5$, which is the $40 \mathrm{Ar} / 36 \mathrm{Ar}$ ratio in the atmosphere; and the correction factors for interfering $\mathrm{Ar}$ isotopes are: $C_{2}=\left(36 \mathrm{Ar} / 37_{\mathrm{Ar}}\right)_{\mathrm{Ca}}=2.72 \times 10^{-4}, C_{3}=\left({ }^{40} \mathrm{Ar} / 39 \mathrm{Ar}\right)_{\mathrm{K}}=5.9 \times$ $10^{-3}$, and $C_{4}=\left({ }^{39} \mathrm{Ar} /{ }^{37} \mathrm{Ar}\right)_{\mathrm{Ca}}=6.33 \times 10^{-4}$. These values of $C_{2}, C_{3}$, and $C_{4}$ used to correct the data are those of Dalrymple and Lanphere (1971) for Ca and K salts irradiated at the U. S. Geological Survey TRIGA Reactor in Denver.

c40 $\mathrm{Ar}_{\mathrm{r}}=$ radiogenic ${ }^{40} \mathrm{Ar} ;{ }^{36} \mathrm{Ar}_{\mathrm{Ca}}=$ calcium-derived ${ }^{36} \mathrm{Ar}$, calculated using data from Dalrymple and Lanphere (1971).

d Ages were calculated using $t=1 / \lambda 1 \mathrm{n}\left(1+J\left({ }^{40} \mathrm{Ar} /{ }^{39} \mathrm{Ar}_{\mathrm{K}}\right)\right.$, where $1 / \lambda=1.885 \times 10^{9} \mathrm{yr}$ and $J$ is a measure of the integrated fast neutron flux as found from the monitor mineral data. Analytical precision is a $2 \sigma$ error based on extrapolation of data points.

radiometrically more closely calibrated than that of van Hinte (1976). They suggest an age of 86 m.y. for the Coniacian/Santonian boundary. This age indicates the deepest breccia to be 95 m.y. old. Both these dates exceed, but are compatible with, the K-Ar hornblende crystallization age.

Seismic profiles and sediment accumulation rates suggest that a few tens of meters separate the lowest recovered breccia from original oceanic crust (see Site 382 Report, this volume). Extrapolation of Campanian/Coniacian Sediment accumulation rates suggests that the crust is probably Cenomanian (92-100 m.y.). Projecting along isochrons of plate motion indicates Site 382 to lie midway between magnetic anomaly $J-6$ (113-117 m.y.) and DSDP Site 10 (73-75 m.y.). Extrapolation of results is compatible with the crustal age (90-100 m.y.) suggested by Pitman and Talwani (1972).

\section{Site 385}

As noted previously, ${ }^{40} \mathrm{Ar} /{ }^{39} \mathrm{Ar}$ analysis of basalt from Sample 385-20-2, 34-42 cm., from Vogel 
TABLE 3

Analy tical Data for $40_{\mathrm{Ar}} / 3^{\mathrm{Ar}}$ Incremental Heating Experiment $\mathrm{a}^{\mathrm{a}}$ Whole Rock 384-22-2, $15-17 \mathrm{~cm}$

\begin{tabular}{|c|c|c|c|c|c|c|c|c|}
\hline $\begin{array}{l}\text { Temp. } \\
\text { (C) }\end{array}$ & $\begin{array}{l}{ }^{40} \mathrm{Ar} /{ }^{39} \mathrm{Ar} \\
\text { (Measured) }\end{array}$ & $\begin{array}{l}{ }^{37} \mathrm{Ar} /{ }^{39} \mathrm{Ar} \\
\text { (Corrected for } \\
37 \mathrm{Ar} \text { Decay) }\end{array}$ & $\begin{array}{l}{ }^{36} \mathrm{Ar} /{ }^{39} \mathrm{Ar} \\
\text { (Measured) }\end{array}$ & $F^{\mathrm{b}}$ & $\begin{array}{c}{ }^{39} \mathrm{Ar} \\
\text { (\% of Total) }\end{array}$ & $\begin{array}{c}{ }^{40} \mathrm{Ar}_{\mathrm{r}}{ }^{\mathrm{c}} \\
(\%)\end{array}$ & $\begin{array}{c}{ }^{36} \mathrm{Ar} C \mathrm{Ca} \\
(\%)\end{array}$ & $\begin{array}{c}\text { Aged }^{\mathrm{d}} \\
\left(\times 10^{6} \mathrm{yr}\right)\end{array}$ \\
\hline 525 & 47.28 & 15.180 & 0.11825 & 13.01 & 42.22 & 27.27 & 3.50 & $103 \pm 5$ \\
\hline 650 & 24.46 & 14.798 & 0.04606 & 11.90 & 24.68 & 48.22 & 8.74 & $94 \pm 4$ \\
\hline 800 & 24.58 & 12.050 & 0.05212 & 9.93 & 13.83 & 40.14 & 6.29 & $79 \pm 5$ \\
\hline 950 & 29.50 & 6.609 & 0.07816 & 6.51 & 6.65 & 22.00 & 2.30 & $52 \pm 4$ \\
\hline 1050 & 20.85 & 98.933 & 0.07560 & 6.59 & 11.25 & 29.63 & 35.59 & $53 \pm 4$ \\
\hline Fusion & 101.64 & 247.243 & 0.38416 & 7.29 & 1.36 & 6.05 & 17.05 & $58 \pm 10$ \\
\hline Total & & & & & & & & \\
\hline Gas & 35.09 & 26.667 & 0.08743 & 11.12 & 100.00 & 31.16 & 8.30 & $88 \pm 5$ \\
\hline
\end{tabular}

aEach temperature was held for one hour. $J=0.004315 \pm 0.000035$. Analysis by John F. Sutter.

$\mathrm{b}_{F}=\left(A_{u}-C_{1} B_{u}+C_{1} C_{2} D_{u}-C\right) /\left(1-C_{4} D_{u}\right)$, where $A_{u}$ is the measured ${ }^{40} \mathrm{Ar} / 39^{3} \mathrm{Ar}$ in the sample; $B_{u}$ is the measured $36 \mathrm{Ar} / 39 \mathrm{Ar}$ in the sample; $D_{u}$ is the ${ }^{37} \mathrm{Ar} / 39 \mathrm{Ar}$ ratio in the sample after correcting for the decay of $37 \mathrm{Ar}\left(t_{1 / 2}=35.1\right.$ days); $C_{1}=295.5$, which is the $40 \mathrm{Ar} / 36_{\mathrm{Ar}}$ ratio in the atmosphere; and the correction factors for interfering $\mathrm{Ar}$ isotopes are: $C_{2}=(36 \mathrm{Ar} / 37 \mathrm{Ar})_{\mathrm{Ca}}=2.72 \times 10^{-4}, C_{3}=\left({ }^{40} \mathrm{Ar} / 39 \mathrm{Ar}\right)_{\mathrm{K}}=5.9 \times$ $10^{-3}$, and $C_{4}=\left({ }^{39} \mathrm{Ar} / 37 \mathrm{Ar}\right)_{\mathrm{Ca}}=6.33 \times 10^{-4}$. These values of $C_{2}, C_{3}$, and $C_{4}$ used to correct the data are those of Dalrymple and Lanphere (1971) for $\mathrm{Ca}$ and K salts irradiated at the U. S. Geological Survey TRIGA Reactor in Denver.

$\mathrm{c} 40 \mathrm{Ar}_{\mathrm{r}}=$ radiogenic ${ }^{40} \mathrm{Ar} ;{ }^{36} \mathrm{Ar}_{\mathrm{Ca}}=$ calcium-derived ${ }^{36} \mathrm{Ar}$, calculated using data from Dalrymple and Lanphere (1971).

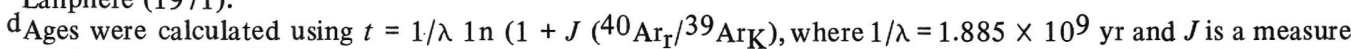
of the integrated fast neutron flux as found from the monitor mineral data. Analytical precision is a $2 \sigma$ error based on extrapolation of data points.

TABLE 4

Analy tical Data for ${ }^{40} \mathrm{Ar} /{ }^{39} \mathrm{Ar}$ Incremental Heating Experiment ${ }^{\mathrm{a}}$ Whole Rock 386-66-1 141-144 cm

\begin{tabular}{|c|c|c|c|c|c|c|c|c|}
\hline $\begin{array}{l}\text { Temp. } \\
\text { (C) }\end{array}$ & $\begin{array}{l}{ }^{40} \mathrm{Ar} /{ }^{39} \mathrm{Ar} \\
\text { (Measured) }\end{array}$ & $\begin{array}{l}{ }^{37} \mathrm{Ar} /{ }^{39} \mathrm{Ar} \\
\text { (Corrected for } \\
{ }^{37} \mathrm{Ar} \text { Decay) }\end{array}$ & $\begin{array}{l}{ }^{36} \mathrm{Ar} /{ }^{39} \mathrm{Ar} \\
\text { (Measured) }\end{array}$ & $F^{\mathrm{b}}$ & $\begin{array}{c}{ }^{39} \mathrm{Ar} \\
\text { (\% of Total) }\end{array}$ & $\begin{array}{c}{ }^{40} \mathrm{Ar}_{\mathrm{r}}{ }^{\mathrm{C}} \\
(\%)\end{array}$ & $\begin{array}{c}{ }^{36} \mathrm{Ar} \\
(\%)\end{array}$ & $\begin{array}{c}\text { Aged } \\
\left(\times 10^{6} \mathrm{yr}\right)\end{array}$ \\
\hline 525 & 460.85 & 81.307 & 1.49421 & 18.24 & 35.77 & 3.76 & 1.48 & $117 \pm 38$ \\
\hline 650 & 118.09 & 136.00 & 0.36779 & 20.15 & 29.51 & 15.60 & 10.06 & $129 \pm 8$ \\
\hline 800 & 155.99 & 149.89 & 0.48559 & 24.26 & 15.90 & 14.08 & 8.43 & $154 \pm 8$ \\
\hline 950 & 310.41 & 152.63 & 0.99760 & 24.72 & 3.20 & 7.19 & 4.17 & $156 \pm 16$ \\
\hline 1050 & 148.07 & 584.11 & 0.59576 & 26.07 & 10.56 & 11.10 & 26.67 & $165 \pm 12$ \\
\hline Fusion & 457.32 & 849.18 & 1.66675 & 53.44 & 5.07 & 5.41 & 13.86 & $323 \pm 48$ \\
\hline Total & & & & & & & & \\
\hline Gas & 250.00 & 202.61 & 0.81500 & 24.13 & 100.00 & 8.42 & 6.76 & $153 \pm 18$ \\
\hline
\end{tabular}

aEach temperature was held for one hour. $J=0.003500 \pm 0.000050$. Analysis by John F. Sutter.

$\mathrm{b}_{F}=\left(A_{u}-C_{1} B_{u}+C_{1} C_{2} D_{u}-C_{3}\right) /\left(1-C_{4} D_{u}\right)$, where $A_{u}$ is the measured ${ }^{40} \mathrm{Ar} / 39^{\mathrm{Ar}}$ in the sample; $B_{u}$ is the measured ${ }^{36} \mathrm{Ar} / 39 \mathrm{Ar}$ in the sample; $D_{u}$ is the ${ }^{37} \mathrm{Ar} / 39 \mathrm{Ar}$ ratio in the sample after correcting for the decay of $37 \mathrm{Ar}\left(t_{1 / 2}=35.1\right.$ days $) ; C_{1}=295.5$, which is the $40 \mathrm{Ar} / 36 \mathrm{Ar}$ ratio in the atmosphere; and the correction factors for interfering $\mathrm{Ar}$ isotopes are: $C_{2}=\left(36_{\left.\mathrm{Ar} /{ }^{37} \mathrm{Ar}\right) \mathrm{Ca}}=2.72 \times 10^{-4}, C_{3}=\left({ }^{40} \mathrm{Ar} / 39^{3} \mathrm{Ar}\right)_{\mathrm{K}}=5.9 \times\right.$ $10^{-3}$, and $C_{4}=\left({ }^{39} \mathrm{Ar} / 37 \mathrm{Ar}\right)_{\mathrm{Ca}}=6.33 \times 10^{-4}$. These values of $C_{2}, C_{3}$, and $C_{4}$ used to correct the data are those of Dalrymple and Lanphere (1971) for $\mathrm{Ca}$ and $\mathrm{K}$ salts irradiated at the U. S. Geological Survey TRIGA Reactor in Denver.

c $40 \mathrm{Ar}_{\mathrm{r}}=$ radiogenic ${ }^{40} \mathrm{Ar} ;{ }^{36} \mathrm{Ar} \mathrm{Ca}=$ calcium-derived ${ }^{36} \mathrm{Ar}$, calculated using data from Dalrymple and Lanphere (1971).

$\mathrm{d}_{\text {Ages were calculated using } t=1 / \lambda} \operatorname{nn}\left(1+J\left({ }^{40} \mathrm{Ar} /{ }^{39} \mathrm{Ar}\right)\right.$, where $1 / \lambda=1.885 \times 10^{9} \mathrm{yr}$ and $J$ is a measure of the integrated fast neutron flux as found from the monitor mineral data. Analytical precision is a $2 \sigma$ error based on extrapolation of data points.

Seamount did not yield a clear plateau or isochron (Figure 2). A total recombined gas age of $54 \pm 3$ m.y. resulted (Table 2). Standard $\mathrm{K}-\mathrm{Ar}$ age dating (Table 6) of another basalt $(385-23-1,139-145 \mathrm{~cm})$ also produced an anomalously young age $(38.3 \pm 15$ m.y. $)$. Weathering apparently precludes whole-rock dating of the Site 385 basalts. Chemical analyses of the basalts (see Houghton, this volume) confirm that the clasts on Vogel are more altered than those from Nashville.
Two hornblende separates from 385-20-2, 112-118 $\mathrm{cm}$, and 385-24-1, 49-54 cm, were also dated by $\mathrm{K}-\mathrm{Ar}$ methods, yielding dates of $82.1 \pm 8$ m.y. and $91.2 \pm 3$ m.y., respectively (Table 6). As determined by both visual inspection and by point counts of montmorillonite and unaltered mineral phases, the first separate was extracted from a more intensely weathered basalt than the second. In order of increasing alteration, the Site 385 basalts are: $24-1,49-54 \mathrm{~cm} ; 20-2,112-118 \mathrm{~cm}$; 
TABLE 5

Analy tical Data for ${ }^{40} \mathrm{Ar} /{ }^{39} \mathrm{Ar}$ Incremental Heating Experiment ${ }^{\mathrm{a}}$ Whole Rock 387-50-1, 22-25 cm

\begin{tabular}{|c|c|c|c|c|c|c|c|c|}
\hline $\begin{array}{l}\text { Temp. } \\
\text { (C) }\end{array}$ & $\begin{array}{l}{ }^{40} \mathrm{Ar} /{ }^{39} \mathrm{Ar} \\
\text { (Measured) }\end{array}$ & $\begin{array}{l}{ }^{37} \mathrm{Ar} /{ }^{39} \mathrm{Ar} \\
\text { (Corrected for } \\
{ }^{37} \mathrm{Ar} \text { Decay) }\end{array}$ & $\begin{array}{l}{ }^{36} \mathrm{Ar} /{ }^{39} \mathrm{Ar} \\
\text { (Measured) }\end{array}$ & $F^{\mathrm{b}}$ & $\begin{array}{c}{ }^{39} \mathrm{Ar} \\
\text { (\% of Total) }\end{array}$ & $\begin{array}{c}{ }^{40} \mathrm{Ar}_{\mathrm{r}}^{\mathrm{C}} \\
(\%)\end{array}$ & $\begin{array}{c}{ }^{36} \mathrm{Ar}_{\mathrm{Ca}} \\
(\%)\end{array}$ & $\begin{array}{c}\text { Age } \\
\left(\times 10^{6} \text { yr }\right)\end{array}$ \\
\hline 525 & 134.55 & 35.606 & 0.12164 & 103.14 & 42.32 & 74.93 & 7.96 & $671 \pm 15$ \\
\hline 650 & 33.82 & 70.302 & 0.08109 & 15.85 & 17.11 & 44.78 & 23.58 & $120 \pm 4$ \\
\hline 800 & 36.64 & 72.083 & 0.08732 & 17.01 & 15.56 & 44.32 & 22.46 & $128 \pm 4$ \\
\hline 950 & 71.90 & 84.826 & 0.20932 & 16.67 & 11.09 & 21.94 & 11.02 & $126 \pm 6$ \\
\hline 1050 & 25.85 & 183.219 & 0.09593 & 13.52 & 10.43 & 46.27 & 51.95 & $102 \pm 4$ \\
\hline Fusion & 77.35 & 423.177 & 0.32607 & 18.82 & 3.49 & 17.83 & 35.30 & $142 \pm 7$ \\
\hline Total & & & & & & & & \\
\hline Gas & 81.79 & 81.592 & 0.12354 & 54.07 & 100.00 & 62.08 & 17.96 & $381 \pm 11$ \\
\hline
\end{tabular}

aEach temperature was held for one hour. $J=0.004145 \pm 0.000040$. Analysis by John F. Sutter.

$\mathrm{b}_{F}=\left(A_{u}-C_{1} B_{u}+C_{1} C_{2} D_{u}-C_{3}\right) /\left(1-C_{4} D_{u}\right)$, where $A_{u}$ is the measured ${ }^{40} \mathrm{Ar} /{ }^{39} \mathrm{Ar}$ in the sample; $B_{u}$ is the measured $36 \mathrm{Ar} / 39 \mathrm{Ar}$ in the sample; $D_{u}$ is the $37 \mathrm{Ar} / 39 \mathrm{Ar}$ ratio in the sample after correcting for the decay of $37 \mathrm{Ar}\left(t_{1 / 2}=35.1\right.$ days); $C_{1}=295.5$, which is the $40 \mathrm{Ar} / 36_{\mathrm{Ar}}$ ratio in the atmosphere; and the correction factors for interfering $\mathrm{Ar}$ isotopes are: $C_{2}=\left(36 \mathrm{Ar} / 37_{\mathrm{Ar}}\right)_{\mathrm{Ca}}=2.72 \times 10^{-4}, C_{3}=(40 \mathrm{Ar} / 39 \mathrm{Ar})_{\mathrm{K}}=5.9 \times$ $10^{-3}$, and $C_{4}=\left({ }^{39} \mathrm{Ar} / 37 \mathrm{Ar}\right)_{\mathrm{Ca}}=6.33 \times 10^{-4}$. These values of $C_{2}, C_{3}$, and $C_{4}$ used to correct the data are those of Dalrymple and Lanphere (1971) for Ca and K salts irradiated at the U. S. Geological Survey TRIGA Reactor in Denver.

${ }^{\mathrm{c}} 40 \mathrm{Ar}_{\mathrm{r}}=$ radiogenic ${ }^{40} \mathrm{Ar} ;{ }^{36} \mathrm{Ar} \mathrm{Ca}=$ calcium-derived ${ }^{36} \mathrm{Ar}$, calculated using data from Dalrymple and Lanphere (1971).

$\mathrm{d}_{\text {Ages were calculated using } t=1 / \lambda} \operatorname{nn}\left(1+J\left({ }^{40} \mathrm{Ar}_{\mathrm{r}} /{ }^{39} \mathrm{Ar}_{\mathrm{K}}\right)\right.$, where $1 / \lambda=1.885 \times 10^{9} \mathrm{yr}$ and $J$ is a measure of the integrated fast neutron flux as found from the monitor mineral data. Analytical precision is a $2 \sigma$ error based on extrapolation of data points.

TABLE 6

K-Ar Dating of Leg 43 Basalts

\begin{tabular}{|c|c|c|c|c|}
\hline $\begin{array}{c}\text { Sample } \\
\text { (Interval in } \mathrm{cm} \text { ) }\end{array}$ & Material & $\begin{array}{l}\mathrm{K}_{2} \mathrm{O} \\
(\%)\end{array}$ & $\begin{array}{c}{ }^{40} \mathrm{Ar}_{\mathrm{r}} \\
\text { (moles/g) }\end{array}$ & Age (m.y.) \\
\hline $382-25-2,91-95$ & Hornblende & $\begin{array}{l}0.1280 \\
0.1275\end{array}$ & $1.707 \times 10^{-10}$ & $88.3 \pm 5.7^{\mathrm{a}}$ \\
\hline $382-23-3,113-118$ & Whole rock & 1.150 & $1.478 \times 10^{-10}$ & $85 \pm 3^{a}$ \\
\hline $385-20-2,112-118$ & Hornblende & $\begin{array}{l}0.1211 \\
0.1208\end{array}$ & $1.500 \times 10^{-10}$ & $82.1 \pm 8^{a}$ \\
\hline $385-24-1,49-54$ & Hornblende & $\begin{array}{l}0.1589 \\
0.1579 \\
0.1583\end{array}$ & $2.187 \times 10^{-10}$ & $91.2 \pm 3^{\mathrm{a}}$ \\
\hline $385-23-1,139-145$ & Whole rock & $\begin{array}{l}2.913 \\
2.910\end{array}$ & $1.665 \times 10^{-10}$ & $38.3 \pm 15^{\mathrm{a}}$ \\
\hline $385-16, \mathrm{CC}, 5-9$ & Whole rock sill & $\begin{array}{l}0.493 \\
0.492\end{array}$ & $1.526 \times 10^{-11}$ & $21.0 \pm 3^{\mathrm{a}}$ \\
\hline $384-22, \mathrm{CC}, 146-148$ & Whole rock & $\begin{array}{l}1.327 \\
1.324\end{array}$ & $2.138 \times 10^{-10}$ & $106.0 \pm 4^{\mathrm{a}}$ \\
\hline $386-66-2,137-140$ & Whole rock & $\begin{array}{l}0.040 \\
0.036\end{array}$ & $7.324 \times 10^{-12}$ & $126.1 \pm 27.2^{b}$ \\
\hline
\end{tabular}

and $23-1,139-145 \mathrm{~cm}$. While $91.2 \pm 3 \mathrm{~m}$.y. is taken as the crystallization age of $24-1,49-54 \mathrm{~cm}$, basalt, some uncertainty must be accepted about the significance of the $82.1 \pm 8 \mathrm{~m}$.y. date for the other hornblende. Although the temptation is to suggest that the optically fresh hornblende of 23-1, 139-145 cm, hints at a later volcanic episode of Vogel than its companion hornblende date, it must be noted that the two ages coincide within their error bars. The two ages may thus date the same period of volcanism, and the larger estimate of error for the younger dated sample may result from greater alteration. We believe the time of cessation of volcanism on Vogel Seamount to be 91.2 \pm 3 m.y.

The oldest nannofossils from Site 385, recovered at a depth of 241 meters, are characteristic of the middle

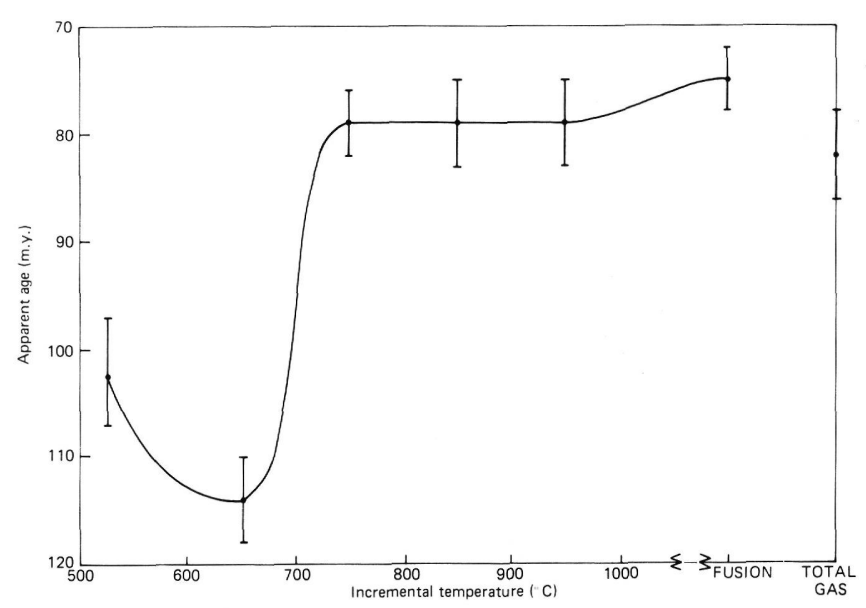

Figure 1. Apparent age in millions of years (m.y.) versus incremental temperature in ${ }^{\circ} \mathrm{C}$ for $40 \mathrm{Ar} / 39 \mathrm{Ar}$ incremental heating analysis of basalt from Sample 382-25-CC, $35-40 \mathrm{~cm}$. Data are presented in Table 1.

to upper lower Maestrichtian (Upper Cretaceous) Lithraphidites quadratus Zone (67-69 m.y.). The fossil assemblage occurs approximately 94 meters above the sediment breccia contact and about 152 meters above the base of the hole. Because the intervening sediments are barren of fossils, a direct estimate of the age of cessation of volcanism on Vogel cannot be made from the sedimentary section. Assuming the volcanogenic debris overlying the breccia accumulated at the same rate as that determined at Site $382(12 \mathrm{~m} / \mathrm{m} . \mathrm{y}$.), the top of the volcaniclastic breccia unit is within the Campanian (75.5-77.5 m.y., Figure 4); this is consistent with the K-Ar age of hornblende from basalt of 


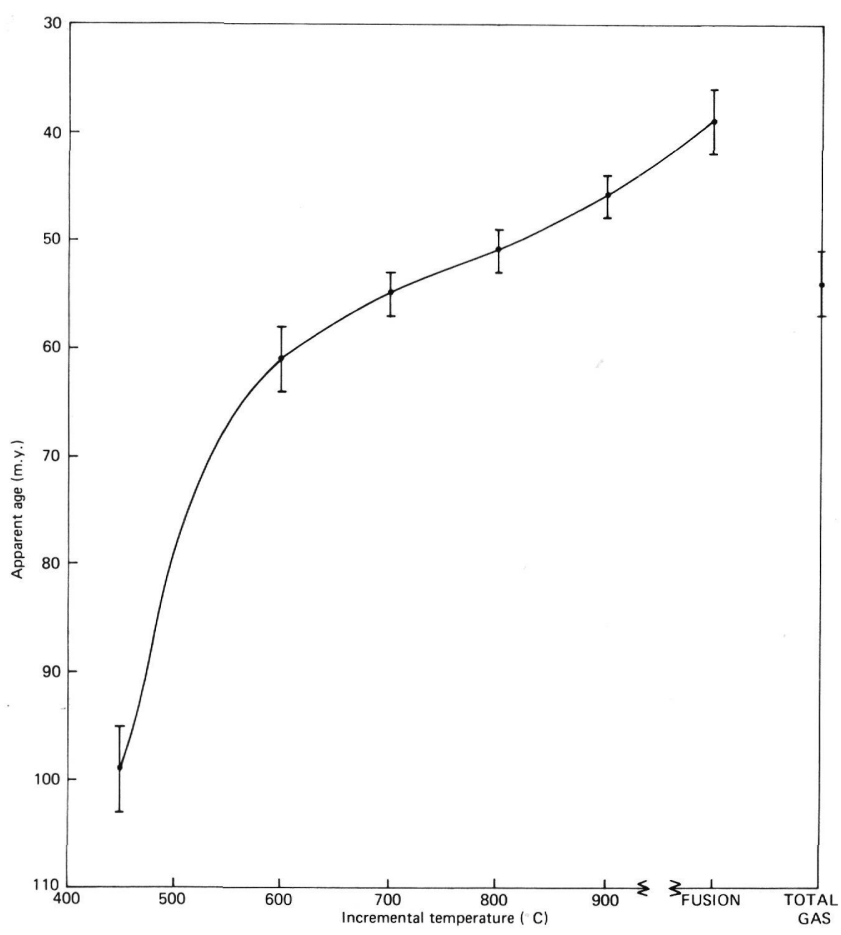

Figure 2. Apparent age in m.y. versus incremental temperature in ${ }^{\circ} \mathrm{C}$ for $40 \mathrm{Ar} /{ }^{39} \mathrm{Ar}$ incremental heating analysis of basalt from Sample 385-20-2, 34-42 cm. Data are presented in Table 2.

Sample 20-2, (112-118 cm). Lower estimated accumulation rates $(\sim 6.4 \mathrm{~m} / \mathrm{m} . \mathrm{y}$.$) if only the rate within the$ volcaniclastic unit is changed, Figure 4 would increase the age of the contact and make it more compatible with radiometric dates for Vogel and Nashville basalts.

A basaltic sill was encountered at a subbottom depth of 283 meters in Site 385. A single K-Ar whole rock age of $21.0 \pm 3$ m.y. was obtained from the freshest basalt in the unit (Table 6). Since the rock is only slightly altered, we believe the date to be valid. The presence of chloritic vesicle fillings, however, suggests a measure of caution. Studies of this unit are continuing.

Geochemical investigations of the sill (see Houghton, this volume) show the basalt to be a large-ion lithophile (LIL) element enriched tholeiite quite similar to a basaltic sill recovered at Site 10, approximately midway between Nashville Seamount and Corner Rise. The Site 10 sill was dated by fission track methods to be $15.9 \pm 1.6$ m.y. old (MacDougall, 1971). As the error of this latter dating method may be relatively large, the two sills could well be contemporaneous.

The appearance of two chemically similar Miocene sills along the strike of the New England seamount chain suggests that Neogene volcanic rejuvenation affected portions of the lineation. Other Miocene events in the North Atlantic are known from Biscay Seamount and the Dome Cantabria (Vigneaux, 1974), Canary Islands (Abdel-Monem et al., 1967; Fuster et al., 1968b), Cape Verde Islands (Machado et al., 1967; Choubert et al., 1968), Iceland (Gale et al., 1966;

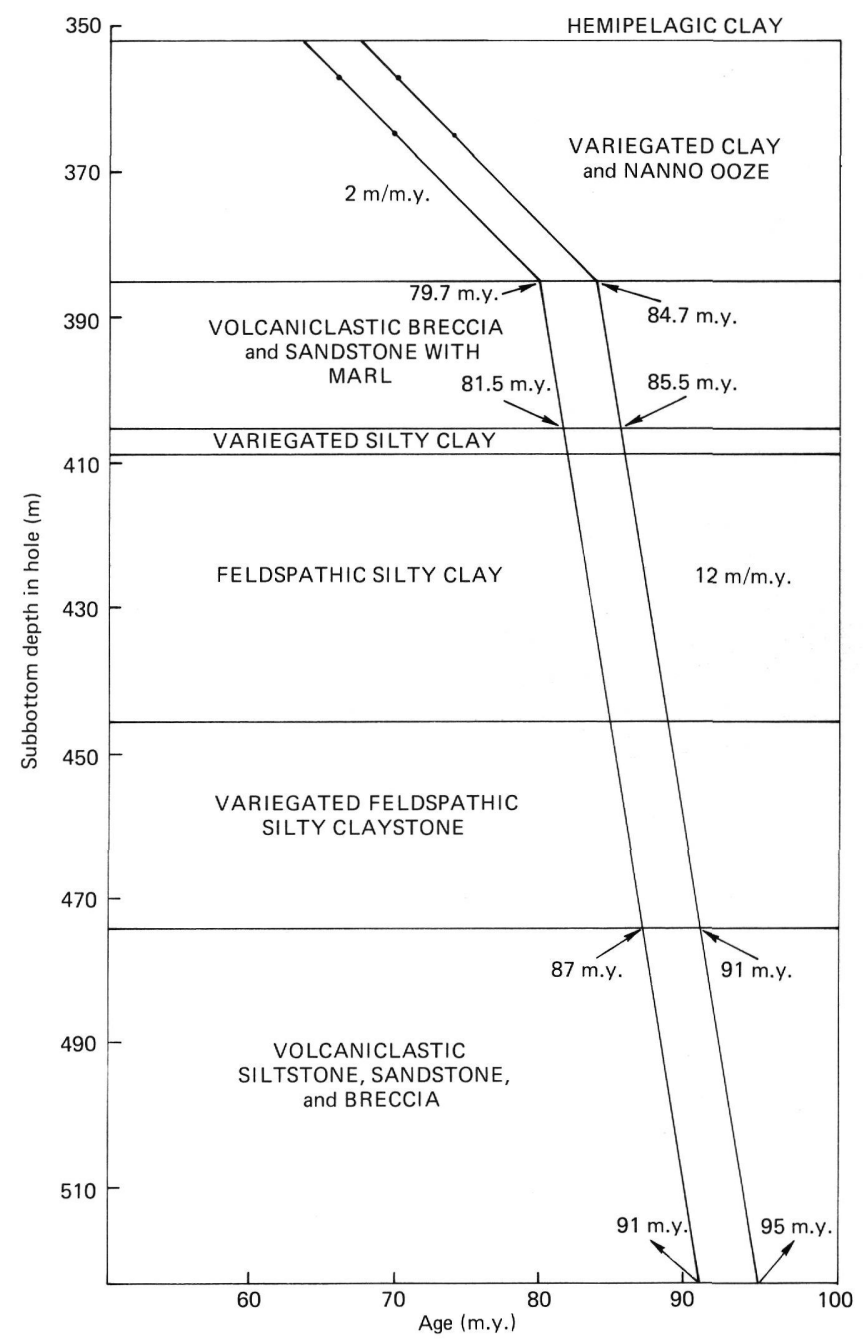

Figure 3. Estimation of ages of tops and bottoms of the volcaniclastic breccia units of Site 382 assuming an average sedimentation rate of $12 \mathrm{~m} / \mathrm{m} . y$. in the volcaniclastic sediments (see Chapter 2). Feldspathic silty clay at 412 meters is paleontologically dated to be at the Coniacian/ Santonian boundary. Using the time scale of van Hinte (1976), this level is 82 m.y. old. Obradovich and Cobban (1975) suggest an age of 86 m.y., instead. These two ages for the Coniacian/Santonian boundary generate the age ranges graphed.

Dagley et al., 1967; Moorbath et al., 1968; Einarsson, 1971; Heer, 1886), Azores (Zbyszewski and da Verga Ferreira, 1962), and Bermuda (Gees, 1969; Reynolds and Aumento, 1974; Hyndman et al., 1974). As Site 10 lies approximately halfway between the New England seamounts and Corner Rise, a relationship between these two features is implied.

\section{THE HOT-SPOT HYPOTHESIS AND THE AGE OF NEW ENGLAND SEAMOUNT VOLCANISM}

Considering the above age dates, the question of progressive versus simultaneous volcanism along the New England seamounts may now be reviewed in relation to other intraplate volcanic lineaments. 


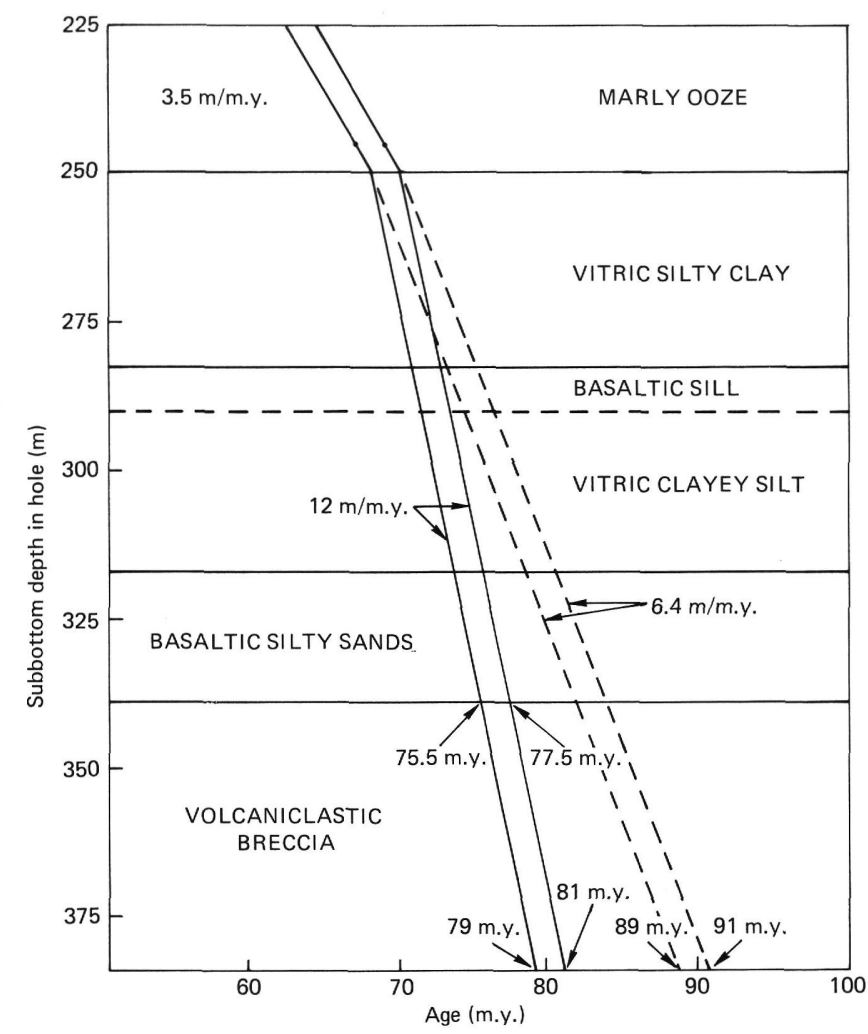

Figure 4. Estimation of ages of the top and bottom of the volcaniclastic breccia at Site 385 assuming an average sedimentation rate within the volcaniclastic unit at Site 382). Marly ooze deposited at $3.5 \mathrm{~m} / \mathrm{m}$.y. (see Chapter 5) is paleontologically dated as middle to upper lower Maestrichtian (67-69 m.y. according to the time scale of van Hinte [1976]) at a sub-bottom depth of 241 meters. The resultant range of dates for the volcaniclastic breccia is shown.

Linear oceanic island chains are currently thought to form either by motion of oceanic plates over relatively stationary magma sources or "hot spots" (Wilson, 1963 ) or by leaking of magma episodically or progressively along an existing or propagating fault or fracture zone (Betz and Hess, 1942; Turcotte and Oxburgh, 1973). The only established test of the hot-spot hypothesis is recognition of age progressions along volcanic lineaments. McDougall $(1964,1971)$ showed that the Hawaiian Island chain increases in age along its length. Morgan (1971, 1972) reported similar results for the Camore Islands. Subsequent investigations along the Hawaiian chain, however, indicate that the generating magma source must also be allowed to migrate (Morgan, 1973). Volcanism within the Gulf of Alaska seamounts (Turner et at., 1973), the Marquesas Islands (Duncan and McDougall, 1974), and the Canary Islands (Dillon and Sougy, 1974) has been similarly shown to be progressive. Three DSDP drill sites along the Line Islands (Leg 17, Site 165; Leg 33, Sites 315 and 316 ), though, suggest nearly simultaneous (79-85 m.y.) volcanic activity (Winterer, Ewing, et al., 1973; Schlanger, Jackson, et al., 1974; Lanphere and Dalrymple, 1976). Similarly, the Cameroun Line
(Geze, 1943; Machens, 1973), Cape Verde Islands (Dillon and Sougy, 1974), and Anti-Atlas Mountains (Choubert et al., 1968) also appear to be coeval. Corroboration of simultaneous volcanism along these chains would mean that at least some linear volcanic features may originate by a process other than plate motion over a mantle hot spot. Proponents of the hotspot hypothesis, however, point to evidence from some supposedly hot-spot-generated igneous traces (e.g., the Yellowstone-Snake River volcanics) that only the initiation of volcanism at each site is time progressive as predicted by the hot-spot model (Smith et al., 1974). Once formed, a volcano may continue to be active after it has moved off its hot spot. As the fracture zone hypothesis is dependent largely upon disproof of the hot-spot hypothesis for any specific locale, traditional distinctions between the two mechanisms are presently in question.

Cases have been advanced for formation of the linear New England seamount chain (Figure 5) by (1) leaking of a magma either progressively or simultaneously along a fracture zone or along the seaward propagation of a Paleozoic or older structural lineament in the Appalachians (Drake et al., 1968; Uchupi et al., 1970; Le Pichon and Fox, 1971); or (2) northwest motion of the North American plate over a nearly fixed mantle hot spot (Coney, 1971; Vogt et al., 1971; Morgan, 1973; Vogt, 1973). Proponents of the former genesis cite truncation of the shelf trough, basement ridge, and possibly the East Coast magnetic anomaly (Drake and Woodward, 1963; Uchupi et al., 1970) and the offset of the Upper Jurassic to Lower Cretaceous Keathley magnetic sequence (Vajk, 1966) as support for their contentions. Vogt et al. (1970), though, believe the Keathley Sequence to be continuous through the area of the New England seamounts. The depth to basement is 500 to 1000 meters lower on the north side of the chain (Vogt, 1973, 1974), suggesting that at least vertical tectonics may have played a part in the history of the lineament. The location, shape, and elongate nature of some of the seamounts within the chain may also be explained by preferential volcanism along pre-existing fractures whose spacing is on the order of plate thickness (Vogt, 1974).

Hot-spot advocates suggest that the White Mountain Magma Series (WMMS) in New England and southwestern Canada is the continental extension of the same plume trace (Griscom and Bromery, 1968; Morgan, 1971; Rhodes, 1971), while partisans of a fracture zone origin of the chain (Ballard and Uchupi, 1972; Houghton and Ballard, in preparation) note that where fracture zones intersect continents ring dike complexes, such as those which characterize the WMMS, generally result from volcanic intrusions. While earthquakes still occur in the White Mountains, the New England seamounts are not seismically active (Keen, 1974). Cretaceous and Tertiary strata along the strike of the seamount chain in the vicinity of the proposed link with the WMMS appear undeformed (Garrison, 1970).

The most reliable radiometric dates determined for Nashville and Vogel seamounts are $88.3 \pm 5.7$ m.y. and $91.2 \pm 3$ m.y., respectively. Although we consider these 


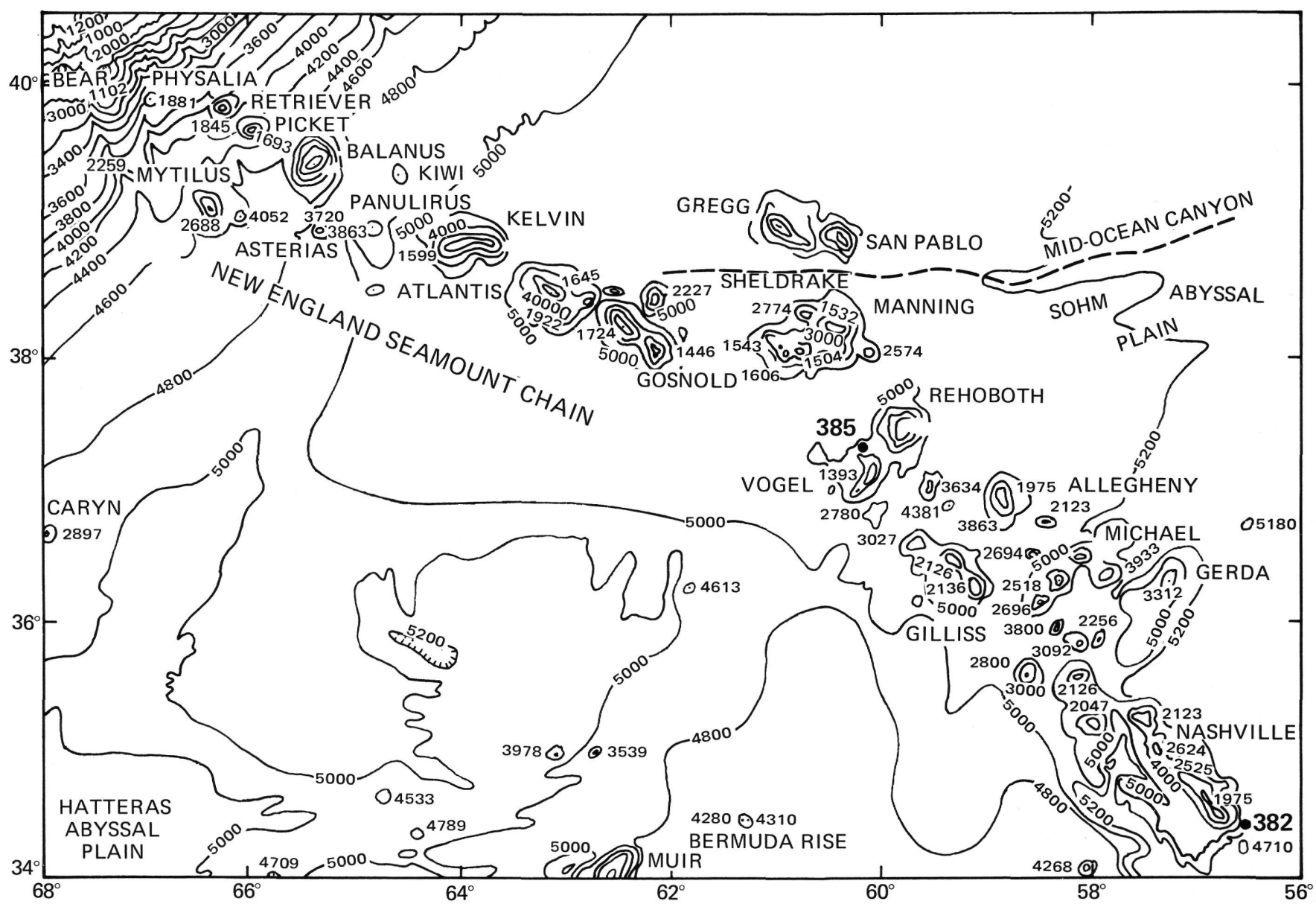

Figure 5. Bathymetric map of the New England seamount chain after Uchupi (1968), showing DSDP Sites 382 and 385 and hornblende crystallization ages at each site. Contours in meters.

dates to be contemporaneous, only the cessation of volcanism was dated. It is of course impossible to conclude on the basis of two drill sites that the entire New England seamount chain displays episodic volcanism or that initiation of volcanism was migratory as required by a hot-spot origin. While a hot-spot origin cannot be excluded for the seamounts, the occurrence of two episodes of volcanism spread over approximately $10+$ m.y., as represented by twin breccia units on both seamounts, must be considered to favor simultaneous volcanic events along a single fault-zone canal.

As with the Line Islands, more dates are necessary to resolve the question. Although it has been demonstrated that only the initiation of volcanism is migratory for hot-spot traces, dating of volcanic cessation can prove profitable. Mid-plate volcanoes are found to have an average constructive life of one million years or less (McDougall, 1964; Duncan and McDougall, 1974). Atlantic volcanoes, like the New England seamounts, characteristically display long-lived activity (McDougall, personal communication, 1976). Many of these were probably built equally rapidly but experienced minor resurgent volcanism over an extended period of time. Thus, sufficiently spaced seamount dates can still serve to establish a meaningful age trend. It is hoped dating of dredged samples from other seamounts along the chain (underway at WHOI) will provide these dates.

\section{Site 384}

A single basalt core fragment (384-22, CC, 146-148 $\mathrm{cm}$ ), chosen for its lack of amygdaloidal chlorite, gave a K-Ar date of $106 \pm 4$ m.y. (Table 6). Although the apparent-age versus incremental-temperature curve for ${ }^{40} \mathrm{Ar} /{ }^{39} \mathrm{Ar}$ incremental heating analysis of $384-22-2,15-$ $17 \mathrm{~cm}$, basalt does not inspire much confidence (Figure 6 ), the derived total gas age of $88 \pm 5 \mathrm{~m}$.y. (Table 3 ) is consistent with other indicators of regional basement age. Irregularities in the incremental curve are believed to arise from the difficulty of accurately determining the radiogenic ${ }^{40} \mathrm{Ar}$ component of low-potassium basalts and the effects of $\mathrm{Ca}$-derived ${ }^{36} \mathrm{Ar}$ and ${ }^{39} \mathrm{Ar}$ at high temperatures, despite use of the corrections of Dalrymple and Lanphere (1971). Lack of the characteristically youthful age pattern for low temperature increments of basalts affected by a thermal event hints 


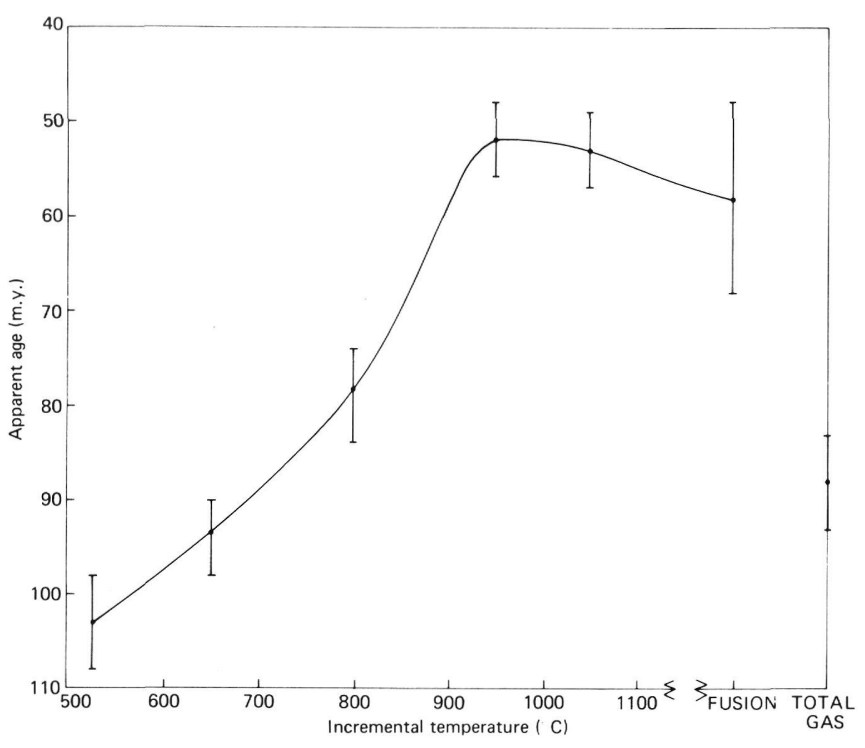

Figure 6. Apparent age in m.y. versus incremental temperature in ${ }^{\circ} \mathrm{C}$ for $40 \mathrm{Ar} / 3^{39} \mathrm{Ar}$ incremental heating analysis of basalt from Sample 384-22-2, 15-17 cm. Data are presented in Table 3.

that hydrothermal activity, which is suggested by the presence of chlorite, has not affected the derived age date.

The oldest nannofossils recovered from Hole 384 occur about 123 meters above basement and are characteristic of the Marthasterites furcatus Zone of the Santonian or Coniacian (Upper Cretaceous). Extrapolation of the average Maestrichtian accumulation rates of $5.3 \mathrm{~m} / \mathrm{m}$.y. suggests the basement to be Aptian (mid-Lower Cretaceous). The occurrence of orbitolinid foraminifers in the sediment immediately overlying the basement basalt also appears to date the contact as Aptian (104-107 m.y.B.P.).

The $J$-anomaly was initially estimated by Vogt et al. (1971) and Pitman and Talwani (1972) as about 135 m.y. old. On the basis of identification of the Keathley Sequence in the Pacific and extrapolation from existing Pacific DSDP basement ages, Larson and Pitman (1972) propose an age on the order of $110 \mathrm{~m}$.y. for the younger end of the Keathley magnetic sequence. Three drill sites near the younger end of the sequence in the Pacific, however, range from mid-Aptian (108 m.y.) to lower Valanginian (130 m.y.) (Larson, 1975). Based on the basement ages of DSDP Sites 166, 303, and 304, van Hinte (1976) places a date of 120 m.y. on anomaly $M-1$. Although most investigators concur the $J$ anomaly should be no more than about $5 \mathrm{~m}$.y. younger than the Keathley Sequence, uncertainty about the latter age has hindered studies of the Cretaceous "quiet zone." If this date is valid, the paleontologic date of 104 m.y. for the $J$-anomaly suggests that the Aptian date for the younger end of the Keathley Sequence is approximately correct within the errors of ocean-seafloor dating techniques. The radiometric age of $88 \pm 5$ m.y., on the other hand, is consistent with van Hinte's (1976) estimate of the $J$-anomaly as $\sim 93$ m.y. Such a basement age would yield nearly a five times greater age spread between the $J$ and $M-1$ anomalies.

\section{Site 386}

${ }^{40} \mathrm{Ar} /{ }^{39} \mathrm{Ar}$ analysis of Sample $386-66-1,141-144 \mathrm{~cm}$ yields a total gas age of $153 \pm 18 \mathrm{~m}$.y. (Table 4 ). The apparent age versus incremental temperature curve (Figure 7) displays an age increase with temperature, suggesting a thermal event which resulted in the loss of radiogenic ${ }^{40} \mathrm{Ar}$. The presence of a hydrothermal vein cutting the cored basalt section, chlorite and serpentine alterations in the basalt, and the location of Site 386 on the southern edge of a fracture zone valley are consistent with this interpretation. Problems related to dating very altered basalts or possibly excess argon problems, though, cannot be ruled out as responsible.

Another attempt at obtaining a reliable ${ }^{40} \mathrm{Ar} / 39 \mathrm{Ar}$ date for this basalt suggested incremental ages ranging from 68 to $270 \mathrm{~m} . \mathrm{y}$. and a total gas age of $110 \pm 20 \mathrm{~m}$.y. The lack of reproducability in these dates results from the difficulty in measuring radiogenic ${ }^{40} \mathrm{Ar}$ in this very low potassium oceanic basalt. A conventional K-Ar date of $126 \pm 27.2 \mathrm{~m} . \mathrm{y}$. (Table 6) in neighboring 386-66-2, $137-140 \mathrm{~cm}$, basalt was also determined. Based on these analyses, out best estimate of the age of Site 386 is 125 $\pm 25 \mathrm{~m} . \mathrm{y}$.

Unbaked sapropelic claystone immediately overlying the cored basalt is characterized by common Parhabdolithus angustus without $P$. cretacea, indicating basement to be uppermost Aptian to mid-Albian (106112 m.y.). Alteration and low potassium preclude setting closer age limits on the Site 386 basalts. The site is in the Cretaceous "quiet zone" west of the $J$ Anomaly Ridge ( $\sim 104$ m.y.) and east of the younger

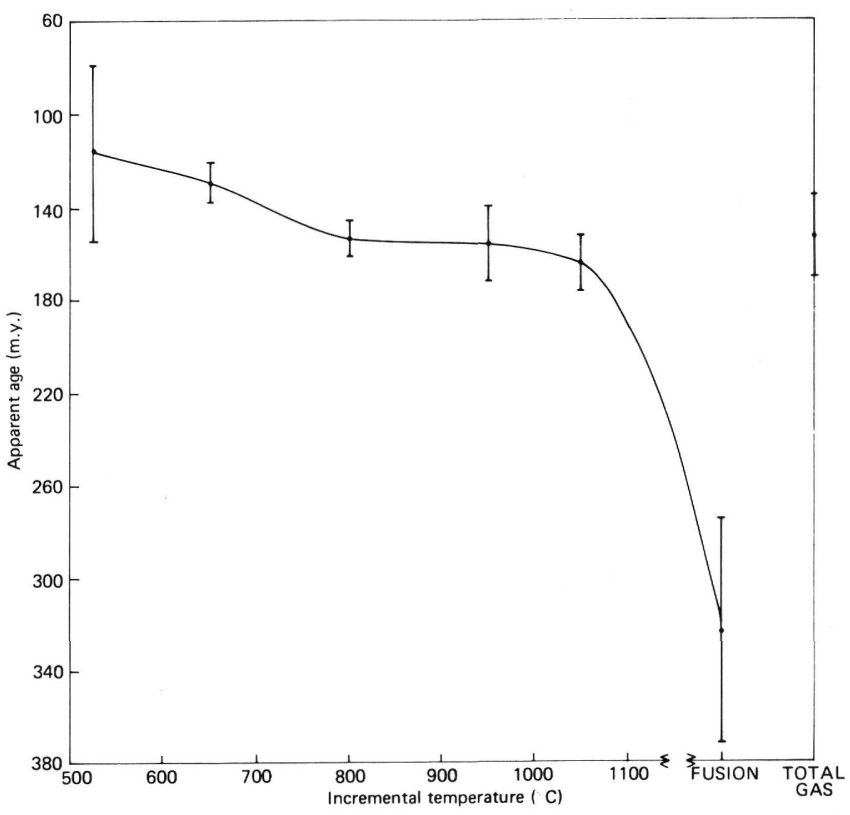

Figure 7. Apparent age in m.y. versus incremental temperature in ${ }^{\circ} \mathrm{C}$ for $40 \mathrm{Ar} /{ }^{39} \mathrm{Ar}$ incremental heating analysis of basalt from Sample 386-66-1, 141-144 cm. Data are presented in Table 4. 
end of the Keathley magnetic sequence ( 120 m.y.), and the radiometric age thus appears to be slightly old. The paleontologic date is consistent with these limitations. The relationship of the site to the fracture zone is ambiguous but is not critical to this interpretation. By analogy with the surveyed Keathley magnetic series west of the site, the maximum offset along the fracture zone is $20 \mathrm{~km}$; but there may, in fact, be no offset at Site 386.

\section{Site 387}

Only one sample of basalt was dated from this hole. ${ }^{40} \mathrm{Ar} /{ }^{39} \mathrm{Ar}$ analysis of Sample $386-50-1,22-25 \mathrm{~cm}$ (Table 6), gave a total gas age of $381 \pm 11$ m.y. The apparent-age versus incremental-temperature curve (Figure 8) displays a poorly defined plateau with a gas retention age of $126 \pm 20$ m.y. Despite the evidence of hydrothermal alteration, which should generate low apparent ages at low increments, the total-gas and lowtemperature apparent ages are anomalously old, perhaps as a result of excess argon. As for Site 386 basalt, the large error bars result from the error in determining radiogenic ${ }^{40} \mathrm{Ar}$ for this very low potassium oceanic basalt. Although alteration effects and cumulative errors make radiometric analysis of this basalt uncertain, our best age estimate at this time is $126 \pm 20$ m.y.

The apparent basement age is well established paleontologically from nannofossils in the immediately overlying limestone and from baked sediment inclusions within the basalt. The Cruciellipsis cuvillieriCretarhabdus angustiforatus assemblage indicates the basalt to be upper Berriasian to lower Valanginian (128-133 m.y.). The radiometric age of the basalt is

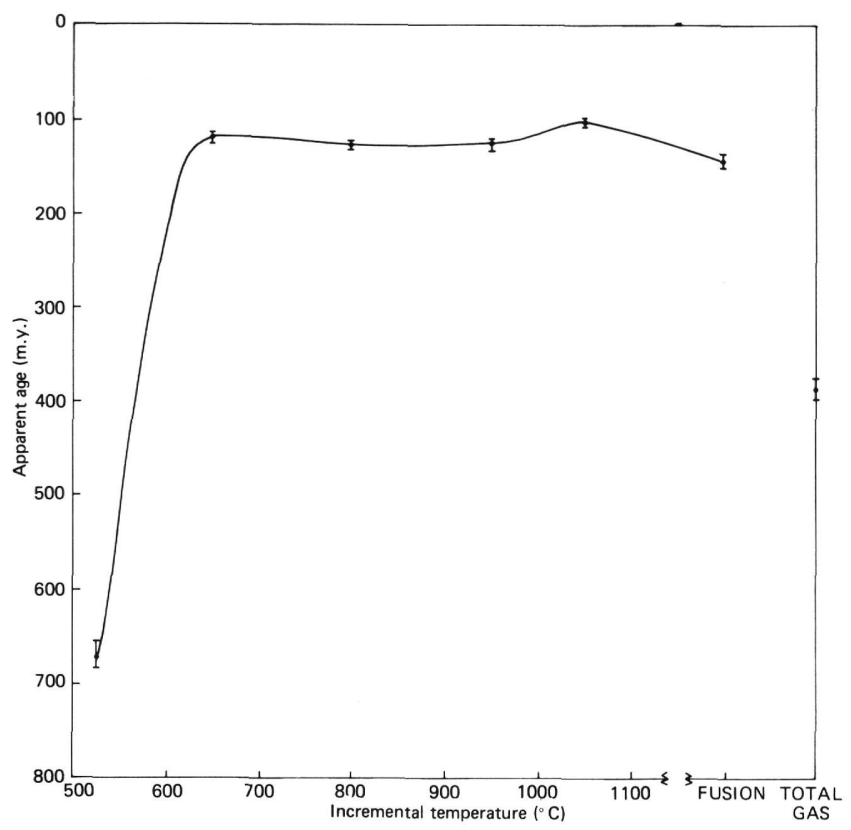

Figure 8. Apparent age in m.y. versus incremental temperature in ${ }^{\circ} \mathrm{C}$ for ${ }^{40} \mathrm{Ar} / 39 \mathrm{Ar}$ incremental heating analysis of basalt from Sample 387-50-1, 22-25 cm. Data are presented in Table 6. within error limits, in agreement. If the basalt represents a sill, it is not significantly younger than true ocean crust.

Site 387 is located near anomaly $M-16$. Larson and Hilde (1975) estimate that crust at the anomaly is about 136 m.y. old, and van Hinte (1976) that it is approximately 133 m.y. old. Paleontological confirmation of this extrapolation provides a basis, along with dating of $M-4$ to $M-9$ and $M-24$ by earlier investigators, for testing the Hayes-Pitman hypothesis that midCreataceous fast spreading accounts for the midCretaceous transgression (Hayes and Pitman, 1970).

\section{AGE DATING CONSTRAINTS ON THE CRETACEOUS HISTORY OF THE WESTERN NORTH ATLANTIC}

In the western North Atlantic the sea-floor magnetic anomaly record is incomplete (Figure 9). Between anomaly 32 and the Bermuda discontinuity, the magnetic reversal sequence is jumbled and only uncertainly correlatable. West of the Bermuda discontinuity is a $360-\mathrm{km}$-wide belt of disturbed anomalies comprising about 25 correlative anomalies. The ages of lineations within this Keathley Sequence ( $M$-Series) have been revised downward in recent years; they are believed to have formed in the Late Jurassic to Early Cretaceous interval. Larson and Pitman (1972) suggest that the sequence may range from 110 to $135 \mathrm{~m}$.y. in age, while van Hinte (1976) prefers a 120 to 145 m.y. age span for the series. The age of sediment overlying basement in DSDP drill sites (Table 7) and the projected ages of van Hinte (1976) from paleontologic controls and those of Pitman and Talwani (1972) from artificial plate tectonic flow lines are shown in Figure 9.

The 106-112 m.y. date for Site 386 confirms the rapid pulse of sea-floor spreading between 110 and 85 m.y. suggested by Larson and Pitman (1972). The average half spreading rate between anomaly 32 (70 m.y.) and Site 385 ( 109 m.y.) is determined to be $\sim 2.9$ $\mathrm{cm} /$ year. This value is in good agreement with the 2.7 $\mathrm{cm} /$ year rate predicted by Larson and Hilde (1975). The principal uncertainty in the determined average spreading rate is in absolute dating of the paleontologic upper Aptian/lower Albian for Site 386. The Hayes-Pitman hypothesis suggests that this midCretaceous episode of fast spreading accounts for the worldwide mid-Cretaceous transgression.

Near the middle of the Keathley Sequence, a pronounced change occurs in basement topography of the central western Bermuda Rise from smooth in the west to rough in the east. Because this transition seemingly correlates with a sea floor isochron in the region, the change in topography has been attributed to a change in the average spreading rate at the time of crustal formation. Slowly spreading ridges tend to produce more irregular basement topography than more rapidly spreading ridges. However, dates of sediment immediately overlying basement at Sites 105 (145 m.y.), 387 (130 m.y.), and 386 (110 m.y.) suggest a spreading rate of $1.7 \mathrm{~cm} /$ year east of $M-15 / M-16$ and about 2.1 


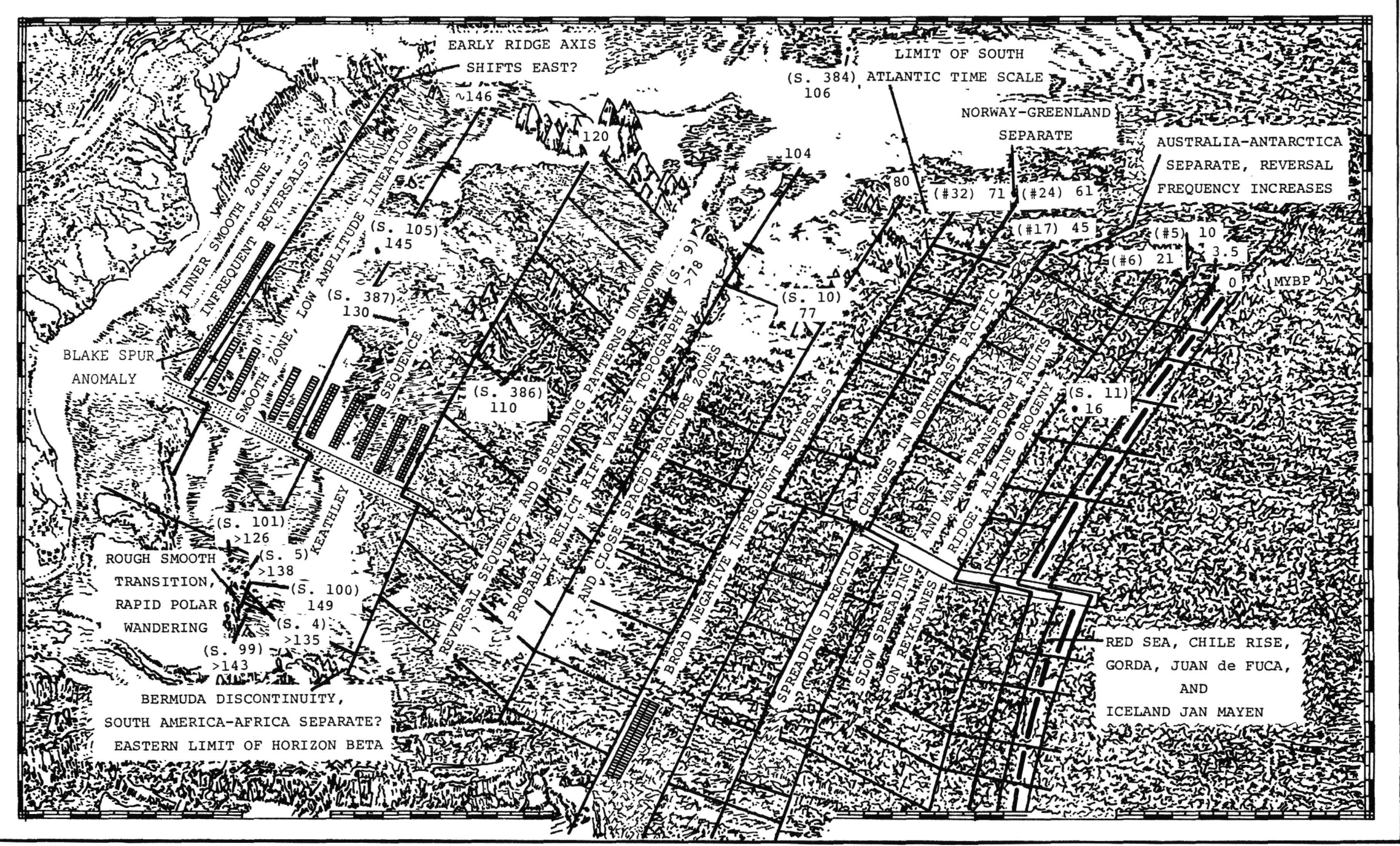

Figure 9. Relief map of the western North Atlantic showing the major changes in magnetic character. Anomalies 0 to 24 are dated according to Pitman and Talwani (1972) on the basis of artificial plate tectonic flow lines. Ages determined from the palonetolbgic time scale of van Hinte (1976) are used for anomalies 32 and older. The best determinations of DSDP basement ages (radiometric or paleontologic) are also shown. Minimum ages determined by the oldest sediment when basement was not reached are shown for Sites 4, 5, 9, and 99. Methods and sources are presented in Table 8. 
TABLE 7

Summary of Western North Atlantic Basement Ages

\begin{tabular}{|c|c|c|c|c|c|}
\hline Site & $\begin{array}{c}\text { Inferred } \\
\text { Basement } \\
\text { Age (m.y.) }\end{array}$ & Material & Method & Age (m.y.) & Source \\
\hline 4 & 148 & $\begin{array}{l}\text { Oldest } \\
\text { sediment }\end{array}$ & Nannofossils & $>135$ & $\begin{array}{l}\text { Ewing, Worzel, } \\
\text { et al. (1969) }\end{array}$ \\
\hline 5 & 148 & $\begin{array}{l}\text { Oldest } \\
\text { sediment }\end{array}$ & Nannofossils & $>138$ & $\begin{array}{l}\text { Ewing, Worzel, } \\
\text { et al. (1969) }\end{array}$ \\
\hline 9 & 107 & $\begin{array}{l}\text { Oldest } \\
\text { sediment }\end{array}$ & Nannofossils & $>78$ & $\begin{array}{l}\text { Peterson, Edgar, } \\
\text { et al. (1970) }\end{array}$ \\
\hline 10 & 77 & $\begin{array}{l}\text { Sediment over } \\
\text { basement }\end{array}$ & Nannofossils & 77 & $\begin{array}{l}\text { Peterson, Edgar, } \\
\text { et al. (1970) }\end{array}$ \\
\hline 11 & 18 & $\begin{array}{l}\text { Sediment over } \\
\text { basement }\end{array}$ & Nannofossils & 16 & $\begin{array}{l}\text { Peterson, Edgar, } \\
\text { et al. (1970) }\end{array}$ \\
\hline 98 & 158 & $\begin{array}{l}\text { Oldest } \\
\text { sediment }\end{array}$ & Foraminifers & $>78$ & $\begin{array}{l}\text { Hollister, Ewing, } \\
\text { et al. (1972) }\end{array}$ \\
\hline 99 & 144 & $\begin{array}{l}\text { Oldest } \\
\text { sediment }\end{array}$ & Nannofossils & $>143$ & $\begin{array}{l}\text { Hollister, Ewing, } \\
\text { et al. (1972) }\end{array}$ \\
\hline 100 & 148 & $\begin{array}{l}\text { Sediment over } \\
\text { basement }\end{array}$ & Nannofossils & 149 & $\begin{array}{l}\text { Hollister, Ewing, } \\
\text { et al. (1972) }\end{array}$ \\
\hline 101 & 150 & $\begin{array}{l}\text { Oldest } \\
\text { sediment }\end{array}$ & Foraminifers & $>126$ & $\begin{array}{l}\text { Hollister, Ewing, } \\
\text { et al. (1972) }\end{array}$ \\
\hline 105 & 147 & $\begin{array}{l}\text { Sediment over } \\
\text { basement }\end{array}$ & Nannofossils & 145 & $\begin{array}{l}\text { Hollister, Ewing, } \\
\text { et al. (1972) }\end{array}$ \\
\hline \multirow[t]{4}{*}{382} & \multirow[t]{4}{*}{96} & $\begin{array}{l}\text { Whole rock } \\
\text { Whole rock }\end{array}$ & $\begin{array}{l}{ }^{40} \mathrm{Ar} /{ }^{39} \mathrm{Ar} \text { plateau } \\
40 \mathrm{Ar} / 39 \\
39 \text { total gas }\end{array}$ & $\begin{array}{l}79 \pm 4 \\
82 \pm 4\end{array}$ & $\begin{array}{l}\text { This volume } \\
\text { This volume }\end{array}$ \\
\hline & & Whole rock & $\mathrm{K}-\mathrm{Ar}$ & $85 \pm 3$ & This volume \\
\hline & & Hornblende & $\mathrm{K}-\mathrm{Ar}$ & $88.3 \pm 5.7$ & This volume \\
\hline & & Sediment & $\begin{array}{l}\text { Paleontologic } \\
\text { extrapolation }\end{array}$ & $91-95$ & This volume \\
\hline \multirow[t]{5}{*}{385} & \multirow[t]{5}{*}{108} & Whole rock & ${ }^{40} \mathrm{Ar} /{ }^{39} \mathrm{Ar}$ total gas & $54 \pm 3$ & This volume \\
\hline & & Whole rock & $\mathrm{K}-\mathrm{Ar}$ & $38.3 \pm 15$ & This volume \\
\hline & & Hornblende & $\mathrm{K}-\mathrm{Ar}$ & $82.1 \pm 8$ & This volume \\
\hline & & Hornblende & $\mathrm{K}-\mathrm{Ar}$ & $91.2 \pm 3$ & This volume \\
\hline & & Sediment & $\begin{array}{l}\text { Paleontologic } \\
\text { extrapolation }\end{array}$ & $79-81$ & This volume \\
\hline \multirow[t]{3}{*}{384} & \multirow[t]{3}{*}{93} & Whole rock & $40 \mathrm{Ar} / 39 \mathrm{Ar}$ total gas & $88 \pm 5$ & This volume \\
\hline & & Whole rock & $\mathrm{K}-\mathrm{Ar}$ & $106 \pm 4$ & This volume \\
\hline & & $\begin{array}{l}\text { Sediment over } \\
\text { basement }\end{array}$ & $\begin{array}{l}\text { Orbitoline } \\
\text { foraminifers }\end{array}$ & $104-107$ & This volume \\
\hline \multirow[t]{3}{*}{386} & \multirow[t]{3}{*}{114} & Whole rock & $40 \mathrm{Ar} / 39 \mathrm{Ar}$ total gas & $153 \pm 18$ & This volume \\
\hline & & Whole rock & ${ }^{40} \mathrm{Ar} /{ }^{39} \mathrm{Ar}$ to tal gas & $110 \pm 20$ & This volume \\
\hline & & $\begin{array}{l}\text { Claystone } \\
\text { overlying } \\
\text { basement }\end{array}$ & Nannofossils & $106-112$ & This volume \\
\hline \multirow[t]{2}{*}{387} & \multirow[t]{2}{*}{138} & $\begin{array}{l}\text { Whole rock } \\
\text { Whole rock }\end{array}$ & $\begin{array}{l}40 \mathrm{Ar} / 39 \mathrm{Ar} \text { total gas } \\
40 \mathrm{Ar} / 39 \mathrm{Ar} \text { plateau }\end{array}$ & $\begin{array}{l}381 \pm 11 \\
126 \pm 20\end{array}$ & $\begin{array}{l}\text { This volume } \\
\text { This volume }\end{array}$ \\
\hline & & $\begin{array}{l}\text { Limestone } \\
\text { overlying and } \\
\text { within basalt }\end{array}$ & Nannofossils & $128-133$ & This volume \\
\hline
\end{tabular}

a Inferred basement ages are extrapolated from the time scale of van Hinte (1976).

$\mathrm{cm} /$ year west of the anomaly, consistent with the predicted relationship. We believe that any error may lie in the date of Site 387 basement. Basalt recovered at that site represents a sill. An older true basement age would suggest an even more rapid spreading rate west of anomaly $M-15$.

Drilling at Sites 101, 386, and 387 suggests that black clay deposition in the western North Atlantic Basin began at least by the late Valanginian and persisted in some areas at least into the Maestrichtian. If the sapropelic sediment is simply related to high surface productivity, then distribution patterns suggest a longer ranging period in the western portion of the basin; however, if the black clay deposition resulted from deep-water stagnation, circulation barriers must have developed coincident with the initiation of euxinic conditions. Widespread demise of Albian-Aptian barrier reefs along the eastern margin of North America and organic carbon fluctuation curves within the black clays of Sites 386 and 387 suggest that extensive basinwide stagnation may not have developed until early Albian time (J-Anomaly Ridge), which extends south of the Grand Banks, may have prohibited free circulation within the North Atlantic during its lifetime as a highstanding feature. An Albian basement age of $104 \pm 6$ m.y. suggests the ridge could not have been a contributing factor to the onset of stagnation but may have aided to block bottom-water circulation during the height of black clay deposition in the basin.

\section{ACKNOWLEDGMENTS}

We wish to thank John Sutter and Robert Duncan for ${ }^{40} \mathrm{Ar} /{ }^{39} \mathrm{Ar}$ analyses and data reduction and Robert Duncan and Krueger Enterprises, Inc., for conventional K-Ar age determinations. Special thanks are extended to Northeast Utilities Service Company for providing financial support for this project. Ian McDougall, Patrick M. Hurley, and Stan Hart provided useful and critical comment. This paper is Contribution No. 3850 of the Woods Hole Oceanographic Institution.

\section{REFERENCES}

Abel-Monem, A., Watkins, N. D. and Gast, P. W., 1967. $\mathrm{K}-\mathrm{Ar}$ geochronology and paleomagnetic studies of the volcanism on the Canary Islands (abstract), Geol. Soc. Am. 1967 Meeting, New Orleans.

Ballard, R. D. and Uchupi, E., 1972. Carboniferous and Triassic rifting: A preliminary outline of the tectonic history of the Gulf of Maine, Geol. Soc. Am. Bull., v. 83, p. 2285-2302.

Betz, F., and Hess, H. H., 1942. The floor of the North Pacific Ocean, Geogr. Rev., v. 32, p. 99-116.

Choubert, G., Charlot, R., Faure-Muret, A., Hottinger, L., Marcais, J., Tisserant, D., and Vidal P., 1968. Note preliminaire sur le volcanisme messinien-"pontien" au Maroc, C. R. Acad. Sci., Paris, Ser. D, v. 266, p. 197-199.

Coney, P. J., 1971. Cordilleran tectonic transitions and motions of the North American plate, Nature, v. 223, p. 462-465.

Dagley, P., Wilson, R. L., Ade-Hall, J. M., Walker, G. P. L., Haggerty, S. E., Sigurgeirsson, T., Watkins, N. D., Smith, P. J., Edwards, J., and Grasty, R. L., 1967. Geomagnetic polarity zones for Icelandic lavas, Nature, v. 216, p. 25-29.

Dalrymple, G. B. and Lanphere, M. A., 1969. Potassiumargon dating: principles, techniques, and applications to geochronology: San Francisco (Freeman \& Co.).

Dalrymple, G. B. and Lanphere, M. A., 1971. ${ }^{40} \mathrm{Ar} /{ }^{39} \mathrm{Ar}$ technique of K-Ar dating: A comparison with the conventional technique, E.P.S.L., v 12, p. 300-308.

Dillion, W. P. and Sougy, I. M. A., 1974. Geology of West Africa and Canary and Cape Verde Islands. In Nairn, A. E. M. and Stehli, F.G. (Eds.), The ocean basins and margins, 2. The North Atlantic: New York (Plenum Press), p. 315390.

Drake, C. L. and Woodward, H. P., 1963. Appalachian curvature, wrench faulting, and off-shore structures, N.Y. Acad. Sci. Trans., v. 26, p. 48-63.

Drake, C. L., Ewing, J. I. and Stockard, H., 1968. The continental margin of the eastern United States, Canadian J. Earth Sci., v. 5, p. 993-1010.

Duncan, R. A. and McDougall, I., 1974. Migration of volcanism with time in the Marquesas Islands, French Polynesia, E.P.S.L., v. 21, p. 414-420.

Einarsson, T,. 1971. Jardfraedi: Reykjavik (Heimskringla).

Ewing, M., Worzel., J. L., et al., 1969. Initial Reports of the Deep Sea Drilling Project, v. 1: Washington (U.S. Government Printing Office).

Fisher, D.E., Bonatti, O., Joensuu, O., et al., 1968. Ages of Pacific deep-sea basalts, and spreading for the sea floor, Science, v. 16, p. 1106-1107.

Fuster, J. M., Fernandez Santin, A., and Sagredo, J., 1968a. Geologia y volcanologia de las Islas Canarias-Lanzarote: 
Inst. “Lucas Mallada," Cansejo Sup. Investig. Cient., Madrid.

Fuster, J. M., Hernandez-Pacheco, A., Munoz, M., Rodriquez Badiola, E., and Garcia Cacho, L., 1968b. Geologia y volcanologia de las Islas Canarias-Gran Canaria: Inst. “Lucas Mallada,"' Consejo Sup. Investig. Cient., Madrid.

Gale, N. H., Moorbath, S., Simmons, G., and Walker, G. P. L., 1966. K-Ar ages of acid intrusive rocks from Iceland, E.P.S.L., v. 1, p. 284-288.

Garrison, L. C., 1970. Development of continental shelf south of New England, Am. Assoc. Petrol. Geol. Bull., v. 54 , p. $90-124$.

Gees, R. A., 1969. The age of the Bermuda seamount, Maritime Sed., v. 5, p. 56-57.

Geze, B., 1943. Geographi Physique et Geologie du Cameroun Occidental, Mem. Mus. Nat. Hist. Nat., n. ser., v. 17, p. 1-272.

Griscom, E. and Bromery, R. W., 1968. Geologic interpretation of aeromagnetic data for New England. In E-an Zen, et al. (Eds.), Studies in Appalachian geology: northern and maritime: New York (Interscience), p. 425-430.

Hayes, D. E., Pitman, W. C., III., 1970. Magnetic lineations in the North Pacific, In Hays, J. D. (Ed.), Geological investigations of the North Pacific, Geol. Soc. Am. Mem. 64, p. 291-314.

Heer, O., 1868. Die Miocene Flora von Island, Flora Fossilis Arctica, v. 1 (III).

Hollister, C. D., Ewing, J. I., et al., 1972. Initial Reports of the Deep Sea Drilling Project, v. 11: Washington (U.S. Government Printing Office).

Houghton, R. L. and Ballard, R. D., in preparation. Tectonic and petrologic observations of the New England Seamounts.

Hyndman, R. D., Muecke, G. K., and Aumento, F., 1974. Deep drill 1972, heat flow and heat production in Bermuda, Canadian J. Earth Sci., v. 11, p. 809-818.

Ingamells, C. O., 1970. Lithium metaborate flux in silicate analysis, Anal. Chim. Acta., v. 52, p. 323-334.

Keen, M. J., 1974. The continental margin of eastern North American, Flordia to newfoundland. In Nairn, A.E.M. and Stehli, F. G. (Eds.), The ocean basics and margings, 2. The North Atlantic: New York (Plenum Press), p. 41-78.

Lanphere, M. A. and Dalrymple, G. B., 1967. K-Ar and Rb$\mathrm{Sr}$ measurements on P-207, the U.S.G.S. interlaboratory standard muscovite, Geochim. Cosmochim. Acta, v. 31, p. 1091.

1976. K-Ar ages of basalts from DSDP Leg 33: Sites 315 (Line Islands) and 317 (Manihiki Plateau). In Schlanger, S. O., Jackson, E. D., et al., Inital Reports of the Deep Sea Drilling Project, v. 33: Washington (U. S. Government Printing Office), p. 649-653.

Larson, R. L., 1975. Late Jurassic sea-floor spreading in the eastern Indian Ocean, Geology, v. 3, p. 69-71.

Larson, R. L. and Hilde, T. C., 1975. A revised time scale of magnetic reversals for the early Cretaceous and late Jurassic, J. Geophys. Res., v. 80, p. 2586-2594.

Larson, R. L. and Pitman, W. C., 1972. World-wide correlation of Mesozoic magnetic anomalies, and its implications, Geol. Soc. Am. Bull., v. 83, p. 3645-3662.

Le Pichon, X. and Fox, P. J., 1971. Marginal offsets, fracture zones and the early opening of the North Atlantic, $J$. Geophys. Res., v. 76, p. 6294-6308.

MacDougall, D., 1971. Deep-sea Drilling: Age and composition of an Atlantic basaltic intrusion, Science, v. 171, p. 1244.
Machado, F., Azeredo Leme, J., and Monjardino, J., 1967. O complexo sienitocarbonatitico da ilh Brava, Cabo Verde, Garcia de Orta, Lisboa, v. 15, p. 93-98.

Machens, E., 1973. The geologic history of the marginal basins along the north shore of the Gulf of Guinea. In Nairn, A.E.M. and Stehli, F.G. (Eds.), The ocean basins and margins, 1. The South Atlantic: New York (Plenum Press), p. 315-390.

Mankinen, E. A. and Dalrymple G. B., 1972. Electron microprobe evaluation of terrestrial basalts for whole-rock K-Ar dating, E.P.S.L., v. 17, p. 89-94.

McDougall, I., 1964. Potassium-argon ages from lavas of the Hawaiian Islands, Geol. Soc. Am. Bull., v. 75, p. 107-128. 1971. Volcanic island chains and sea floor spreading, Nature, Phys. Sci., v. 231, p. 141-144. 1977. Trace element determinations and potassiumargon dating by mass spectroscopy of neutron-irradiated samples (abstract), EOS, v. 46, p. 125.

Moorbath, S., Sigurdsson, H., and Goodwin, R., 1968. K-Ar ages of the oldest exposed rocks in Iceland, E.P.S.L., v. 4, p. 197-205.

Morgan, W.J., 1971. Convection plumes in the lower mantle, Nature, v. 230, p. 42-43. 1972. Deep mantle convection plumes and plate motions, Am. Assoc. Petrol. Geol. Bull., v. 56, p 203-213. 1973. Plate motions and deep mantle convection. In Shagam, R. (Ed.), Studies in earth and space science: Hess Vol., Geol. Soc. Am. Mem. 132, p. 7-22.

Obradovich, J. D. and Cobban, W. A., 1975. A time-scale for the Late Cretaceous of the western interior of North America, Geol. Assoc. Canada Spec. Pap., v. 13.

Peterson, M. N. A., Edgar, N. T., et al., 1970. Initial Reports of the Deep Sea Drilling Project, v. 2: Washington (U.S. Government Printing Office).

Pitman, W. C., III, and Talwani, M., 1972. Sea-floor spreading in the North Atlantic, Geol. Soc. Am. Bull., v. 83, p. 619-646.

Reynolds, P. H. and Aumento, F., 1974. Deep Drill 1972. Potassium-argon dating of the Bermuda drill core, Canadian J. Earth Sci., v. 11, p. 1269-1273.

Rhodes, R. C., 1971. Structural geometry of subvolcanic ring complexes as related to pre-Cenozoic motions of continental plates, Tectonophysics, v. 12, p. 111-117.

Schlanger, S. O., Jackson, E. D., et al., 1974. Testing a hotspot theory, Geotimes, v. 19, p. 16-20.

Sigurgeirsson, T., 1962. Dating recent basalt by the potassium-argon method, Rept. Phys. Lab. Univ. Iceland, 9 p.

Smith, R. B., Shuey, R. T., Treidline, R. O., et al., 1974. Yellowstone hot spot: New magnetic and seismic evidence, Geology, v. 2, p. 451-455.

Turcotte, D. L. and Oxburgh, E. R., 1973. Mid-plate tectonics, Nature, v. 244, p. 337-339.

Turner, D. L., Forbes, R. B. and Naeser, C. W., 1973. Radiometric ages of Kodiak Seamount and Giacomini Guyot, Gulf of Alaska; Implications for circum-Pacific tectonics, Science, v. 182, p. 579-581.

Uchupi, E., 1968. Long lost mytilus, Oceanus, v. 14, p. 1-7.

Uchupi, E., Phillips, J. D., and Prada, K. E., 1970. Origin and structure of the New England Seamount chain, Deep-Sea Res., v. 17 , p. $483-494$.

Vajk, R., 1966. Marine geophysical survey program 65-67Western North Atlantic and eastern and central north Pacific Ocean, Area I, Magnetics, U.S. Nav. Oceanogr. Off. Contrib., v. 6, p. 1-23.

van Hinte, J. E., 1976. A Cretaceous time scale, Am. Assoc. Petrol. Geol. Bull., v. 60, p. 498-516. 
Vigneaux, M., 1974. The geology and sedimentation history of the Bay of Biscay. In Nairn, A.E.M. and Stehli, F.G. (Eds.), The ocean basins and margins, 2. The North Atlantic: New York (Plenum Press), p. 273-314.

Vogt, P. R., 1973. Early events in the opening of the North Atlantic. In Tarling and Runcorn (Eds.), Implications of continental drift to the earth sciences: New York (Academic Press), p. 693-712.

1974. Volcano spacing, fractures, and thickness of the lithosphere, E.P.S.L., v. 21, p. 235-252.

Vogt, P. R., Anderson, C. N. and Bracey, D. R., 1971. Mesozoic magnetic anomalies, sea-floor spreading, and geomagnetic reversals in the south western North Atlantic, J. Geophys. Res., v. 76, 4796-4823.
Vogt, P. R., Lorentzen, G. R., and Dennis, L. S., 1970. An aeromagnetic survey of the Keathley magnetic anomaly sequence between $54^{\circ} \mathrm{N}$ and $40^{\circ} \mathrm{N}$ in the western North Atlantic, $E O S$, v. 51, p. 274.

Wilson, J. T., 1963. A possible origin of the Hawaiian Islands, Canadian J. Phys., v. 41, p. 863-870.

Winterer, E. L., Ewing, J. I., et al., 1973. Initial Reports of the Deep Sea Drilling Project, v. 17: Washington (U.S. Government Printing Office).

Zbyszewski, G. and da Verga Ferreira, O., 1962. La Faune Miocene de 1' ile de Santa Maria, Communic, de Servicos Geologicos de Portugal, v. 46, p. 247-290. 